\title{
Application of the Thermodynamic Cycle to Assess the Energy Efficiency of Amine-Based Absorption of Carbon Capture
}

\author{
Yaofeng $\mathrm{Xu}{ }^{1,2}$, Shuai Deng ${ }^{1,2, *}$, Li Zhao ${ }^{1}$, Xiangzhou Yuan ${ }^{3}{ }^{\circledR}$, Jianxin Fu ${ }^{1,2}$, Shuangjun $\mathrm{Li}^{1,2}$, \\ Yawen Liang ${ }^{4}$, Junyao Wang ${ }^{1,2}$ and Jun Zhao ${ }^{1}$ \\ 1 Key Laboratory of Efficient Utilization of Low and Medium Grade Energy, Tianjin University, Ministry of \\ Education of China, Tianjin 300350, China \\ 2 International Cooperation Research Centre of Carbon Capture in Ultra-Low Energy-Consumption, \\ Tianjin 300350, China \\ 3 College of Engineering Department of Chemical and Biological Engineering, Korea University, \\ Seoul 02841, Korea \\ 4 Tianjin Newcen Technical Co., Ltd., Tianjin 300384, China \\ * Correspondence: sdeng@tju.edu.cn
}

Received: 22 May 2019; Accepted: 24 June 2019; Published: 28 June 2019

\begin{abstract}
The thermodynamic cycle, as a significant tool derived from equilibrium, could provide a reasonable and rapid energy profile of complicated energy systems. Such a function could strongly promote an in-depth and direct understanding of the energy conversion mechanism of cutting-edge industrial systems, e.g., carbon capture system (CCS) However, such applications of thermodynamics theory have not been widely accepted in the carbon capture sector, which may be one of the reasons why intensive energy consumption still obstructs large-scale commercialization of CCS. In this paper, a kind of thermodynamic cycle was developed as a tool to estimate the lowest regeneration heat $\left(Q_{\text {re }}\right)$ of a benchmark solvent (MEA) under typical conditions. Moreover, $\mathrm{COP}_{\mathrm{CO}_{2}}$, a new assessment indicator, was proposed firstly for energy-efficiency performance analysis of such a kind of CCS system. In addition to regeneration heat and second-law efficiency $\left(\eta_{2 n d}\right)$, the developed $\mathrm{COP}_{\mathrm{CO}_{2}}$ was also integrated into the existing performance analysis framework, to assess the energy efficiency of an amine-based absorption system. Through variable parameter analysis, the higher $\mathrm{CO}_{2}$ concentration of the flue gas, the higher $\mathrm{COP}_{\mathrm{CO}_{2}}$, up to $2.80 \mathrm{in} 16 \mathrm{vt} \%$ and the $Q_{\text {re }}$ was $2.82 \mathrm{GJ} / \mathrm{t}$, when $R_{\mathrm{des}}=1$ and $\Delta T_{\text {heat-ex }}=10 \mathrm{~K}$. The $\eta_{2 \text { nd }}$ was no more than $30 \%$ and decreased with the rise of the desorption temperature, which indicates the great potential of improvements of the energy efficiency.
\end{abstract}

Keywords: thermodynamic cycle; $\mathrm{COP}_{\mathrm{CO}_{2}}$; amine-based absorption; carbon capture; regeneration heat; second-law efficiency

\section{Introduction}

Due to the activities of human beings, the concentration of $\mathrm{CO}_{2}$ - the main greenhouse gases, which accounts for $76 \%$ - has passed 400 ppm and now reached a new high level of 415 ppm, on 13 May 2019 [1,2]. The Intergovernmental Panel on Climate Change (IPCC) indicated the rise of global mean temperature is limited to $1.5^{\circ} \mathrm{C}$ rather than $2.0^{\circ} \mathrm{C}$, and it will definitely bring more benefits to humans and natural ecosystems. At the same time, by 2030, global $\mathrm{CO}_{2}$ emissions need to fall by $45 \%$ compared to 2010 [3,4]. In order to achieve this goal, efforts of all components of our society are required. CCS plays a vital role in the mitigation of climate change, which could contribute $14 \%$ to the reduction of $\mathrm{CO}_{2}$ emission according to the International Energy Agency (IEA) [5]. With the development of CCS technologies, amine-based post-combustion technologies could approach a commercial-scale 
project first, which remains the preferred $\mathrm{CO}_{2}$ capture technology for the short and medium term [6,7]. However, high energy consumption obstructs the popularization and application of CCS [8]. In recent years, many researchers have given much attention to the development of new amine-based solvents. Table 1 summarizes the energy performance of three kinds of new amine-based solvents.

Table 1. Energy consumption performance of different chemical absorbents.

\begin{tabular}{|c|c|c|c|c|}
\hline Classification & Solvent & $\begin{array}{c}\text { Energy } \\
\text { Consumption } \\
(\mathrm{GJ} / \mathrm{t})\end{array}$ & $\begin{array}{l}\text { Energy Performance } \\
\text { Compared to MEA } \\
\text { (Lower Percentage) }\end{array}$ & Ref \\
\hline \multicolumn{5}{|c|}{ Blend of amines } \\
\hline & MEA + MDEA & $2.0-3.7$ & & [9-11] \\
\hline & MEA + AMP & $4.0-6.1$ & & [12] \\
\hline & MDEA + PZ & 2.24 & $27 \%$ & [13] \\
\hline & AMP + DETA & & $35.6-27.7 \%$ & [14] \\
\hline & $\mathrm{AMP}+\mathrm{PZ}$ & $3.0-3.2$ & $10-20 \%$ & {$[15,16]$} \\
\hline & $\mathrm{MEA}+[\mathrm{Bmim}]\left[\mathrm{BF}_{4}\right]$ & & $10-37.2 \%$ & {$[17,18]$} \\
\hline & $\mathrm{MEA}+[\mathrm{Bpy}]\left[\mathrm{BF}_{4}\right]$ & & $7.44-15 \%$ & [19-21] \\
\hline \multicolumn{5}{|c|}{ Water-lean/free } \\
\hline & $\begin{array}{l}\text { 2-fluorophenethylamine }+ \\
\text { Octafluoropentanol }\end{array}$ & $2.2-3$ & $40-50 \%$ & [22] \\
\hline & MEA + Methanol & 2.28 & $24 \%$ & [23] \\
\hline & 2-methoxyethanol + MEA & & $55 \%$ & [24] \\
\hline \multicolumn{5}{|c|}{ Phase change absorbents } \\
\hline & $\mathrm{MEA}+\mathrm{SA}$ & 2.55 & $43.6 \%$ & [25] \\
\hline & $\mathrm{DMX}$ & 2.1 & & [26] \\
\hline & TBS & 2.5 & & [27] \\
\hline & MAPA + DEEA & 2.2 & & [28] \\
\hline & TETA + DEEA & 2.46 & $35 \%$ & [29] \\
\hline & DEEA + AEEA & 2.58 & & [30] \\
\hline & DEAPD + TETA & 2.7 & $29 \%$ & [29] \\
\hline & TMPDA + TETA & 1.83 & $52 \%$ & [29] \\
\hline & DMCA + TETA & $2.07-3.92$ & & {$[29,31]$} \\
\hline
\end{tabular}

A blend of amines solvents integrates the properties and advantages of various amines, such as a classic combination of primary amines (e.g., MEA) or secondary amines (e.g., DEA) mixed with tertiary amines (e.g., MDEA) [32,33]. The performance of this kind of solvent, which combines the high reaction rate of primary or secondary amines with the high absorption capacity and lower absorption heat of tertiary amines, has been tested at the pilot scale or even higher scales for many years [34,35]. Additionally, ionic liquids (ILs) are also a kind of modifier, which possess suitable characteristics, such as high thermal stability, nonflammability, and high $\mathrm{CO}_{2}$ solubility [36]. Researchers added ILs into amines in an attempt to improve the absorption ability of solvents and reduce the energy consumption of regeneration [37,38]. Gao et al. [39] added [Bmim] $\left[\mathrm{BF}_{4}\right]$ into MDEA/PZ, with the result showing larger $\mathrm{CO}_{2}$ cyclic capacities, which indicated that the anion species of ILs could lower the sensible heat. However, one of the inevitable problems with IL solvents is that the viscosity of the solution will increase. Then, as a result, it brings a decrease of the mass transfer rate and reaction rate along with the absorption process $[40,41]$. Despite these good advantages, including being environmentally-friendly, the expensive cost of ILs is an obstruction, whose price are up to $1000 \$ / \mathrm{kg}$, limiting its application at large scales [42].

In the regeneration process, due to the high specific heat of water, plenty of heat is used to the sensible heat and the latent heat of steam [43]. Then, a kind of amine-based solvent, water-lean/nonaqueous absorbents, has gain the attention of researchers. The most common method is to reduce the proportion of water in solution, even to water-free. Water-lean or nonaqueous absorbents 
replace the water by organics, such as alcohols and glycols, to maintain the advanced capability of the absorption of $\mathrm{CO}_{2}$, like aqueous amines [44]. However, the changes are not always beneficial to all processes. The high viscosity of the solutions/absorbents leads to poor mass transfer, which strongly affects the absorption capacity $[45,46]$. Furthermore, nonaqueous solvent components with lower molecular weights may pollute the air because of the presence of volatile organic emissions in the exhaust [22]. The feasibility of water-lean/nonaqueous absorbents entails a deeper exploration and higher scale demonstration.

In recent years, phase change solvents have caught the attention of researchers. Phase change solvents are single-phase solvents before absorbing $\mathrm{CO}_{2}$ or being heated, and if the $\mathrm{CO}_{2}$ loading or temperature is changed, they will transform into a two-phase (liquid-liquid or liquid-solid). Then, only the $\mathrm{CO}_{2}$-enriched phase is sent to the regeneration process. There will be a heat decrease due to the mass of the solvents reducing. Liu et al. [30] developed a novel phase change solvent, DEEA (50 wt $\%)$-AEEA $(25 \mathrm{wt} \%)$, with a high $\mathrm{CO}_{2}$ cycle capacity $\left(0.64 \mathrm{~mol} \mathrm{CO}_{2} / \mathrm{mol}\right)$ and a regeneration energy consumption as low as $2.58 \mathrm{GJ} / \mathrm{t}$, which is even cheaper. Shen et al. [29] investigated the $18 \mathrm{kings}$ of amines, which were used as the main components of the phase change solvent. The result revealed that the tertiary amine's alkalinity had a closed relation with the absorption ability, and the lowest heat duty (TMPDA + TETA) was as low as $1.83 \mathrm{GJ} / \mathrm{t}$ in some cases. However, the phase change process remains in a development stage, with a complex process design, extra equipment, and slurry along with a scale-up required, and the stability needs to be further tested [24].

In addition to these, there are also some unique attempts in using a catalyst in amine-based absorption. Leimbrink et al. [47] investigated the enzyme-catalyzed reactive process with an MDEA solvent through lots of experiments, showing the specific reboiler heat duty was $40 \%$ lower than the MEA solvent, and decreased to $2.18 \mathrm{GJ} / \mathrm{t}$ without a special process design. Solid acid catalysts were added into amine solutions or packed columns, such as $\gamma-\mathrm{Al}_{2} \mathrm{O}_{3}$ or HZSM-5 [48] and nanostructured $\mathrm{TiO}(\mathrm{OH})_{2}[49]$, bringing a low desorption temperature. They all concluded that the addition of catalysts was effective in energy reduction to some degree.

In summary, these amine-based methods all bring a certain improvement in the energy reduction of the regeneration process. They all reveal different characteristics of the absorption or desorption process, while being simultaneously accompanied by some limitations. At this stage, considering all aspects, like energy consumption, price, stability, environment pollution, and so on, MEA may not be the best but the most mature solvent, which is used as a benchmark solvent in the CCS field. Single MEA and amine blend solvent remain the best choices for the short and medium term with a tight competition [6]. However, there is a significant difference in the energy consumption in these pilot plants or at a higher scale. From Figure 1, even in similar flue gas conditions $\left(\mathrm{CO}_{2}\right.$ concentration from $9 \%$ to $15 \%$ ), the energy consumption ranges from $2.8 \mathrm{GJ} / \mathrm{t} \mathrm{CO}$ to $7.7 \mathrm{GJ} / \mathrm{t} \mathrm{CO}$, with the details shown in Table 2. This result appeared not only due to the different absorption solvents and facility, but also the different operating conditions and evaluation methods. Thus, this situation indicates that there is room for amine-based absorption to improve the energy efficiency and to lower the cost of CCS.

Table 2. Energy consumption data of large scales CCS projects.

\begin{tabular}{ccccc}
\hline Solvent & $\begin{array}{c}\text { Energy Consumption } \\
(\mathbf{G J} / \mathbf{t})\end{array}$ & $\begin{array}{c}\text { Temperature of } \\
\text { Flue Gas }\left({ }^{\circ} \mathbf{C}\right)\end{array}$ & $\begin{array}{c}\mathbf{C O}_{\mathbf{2}} \text { Concentration of } \\
\text { Flue Gas (\%) }\end{array}$ & Ref \\
\hline MEA & 3.5 & 40 & 12 & {$[50]$} \\
MEA & 3.82 & 127.5 & 13.5 & {$[51]$} \\
MEA & 7.7 & 40 & 13.14 & {$[52]$} \\
MEA & 3.8 & 90 & 13.5 & {$[53]$} \\
MEA & 3.53 & 60 & 13 & {$[54]$} \\
CESAR1 & 2.9 & 60 & 13 & {$[54]$} \\
CESAR2 & 3.46 & 60 & 13 & {$[54]$} \\
MEA & 3.62 & 47 & 12 & {$[55]$} \\
\hline
\end{tabular}


Table 2. Cont.

\begin{tabular}{ccccc}
\hline Solvent & $\begin{array}{c}\text { Energy Consumption } \\
(\mathbf{G J} / \mathbf{t})\end{array}$ & $\begin{array}{c}\text { Temperature of } \\
\text { Flue Gas }\left({ }^{\circ} \mathbf{C}\right)\end{array}$ & $\begin{array}{c}\mathbf{C O}_{\mathbf{2}} \text { Concentration of } \\
\text { Flue Gas (\%) }\end{array}$ & Ref \\
\hline CASTOR1 & 3.58 & 47 & 12 & {$[55]$} \\
CASTOR2 & 3.80 & 47 & 12 & {$[55]$} \\
MEA & 3.48 & 40 & 14.2 & {$[56]$} \\
GUSTAV200 & 2.77 & 40 & 14.2 & {$[56]$} \\
MEA & 5.6 & 51 & 9.0 & {$[57]$} \\
MEA & 4.8 & 51 & 12 & {$[57]$} \\
MEA & 4.5 & 51 & 13.5 & {$[57]$} \\
MEA & 3.8 & 47 & 14 & {$[58]$} \\
MEA & 4.1 & 40 & 15 & {$[59]$} \\
SOLVENTA & 3.1 & 40 & 15 & {$[59]$} \\
SOLVENTB & 2.9 & 40 & 15 & {$[59]$} \\
SOLVENT1 & 2.8 & 60 & 9 & {$[60]$} \\
SOLVENT2 & 3.2 & 60 & 9 & {$[60]$} \\
MEA & 4.0 & 170 & 10.5 & {$[12]$} \\
BLEND1 & 3.8 & 170 & 10.5 & {$[12]$} \\
BLEND2 & 3.6 & 170 & 10.5 & {$[12]$} \\
\hline
\end{tabular}

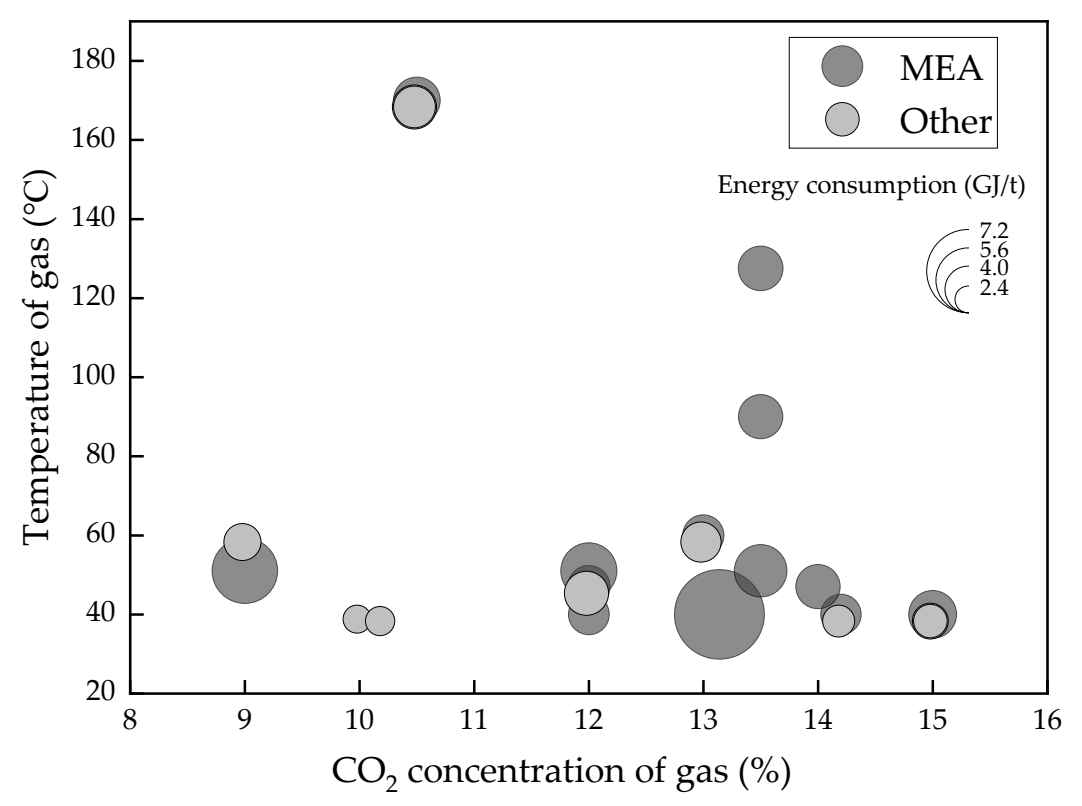

Figure 1. Energy consumption of MEA or blends of large scales CCS projects.

Generally, there are two different kinds of models that are applied to energy analysis of the CCS process. The first type of model, such as the mixed gas separation model, as a tool for separation theory, was formed in the 1940s. It focuses only on the state of the gas before and after separation, thereby calculating the minimum work of separation, which provides a simplified analysis method. House et al. [61] applied the separation model on post combustion CCS and derived an analytic relationship for the energy penalty from the thermodynamics. Douglas et al. [62] examined the relationship between the minimum work of separation and the "separative work" from the theory stage and analyzed their differences in numerical values on specific carbon capture scenarios. However, such a black box model is too idealistic, without the combination of the specific process and operating condition, and cannot effectively guide engineering technology.

The second type of model is mainly used for the simulation of the carbon capture process, such as the widely used equilibrium model and the rate-based model. The equilibrium model uses the basic MESH equilibrium equation assumption, which stipulates that each stage is in thermodynamic 
equilibrium and chemical reaction equilibrium $[63,64]$. Although there is a good match between the simulation results and the experimental results in the temperature and pressure of columns, it also has a drawback, which requires re-implementation of the comprehensive design parameters. Therefore, this kind of process model, just like the experiment method, adjusts the operating parameters to adjust the $\mathrm{CO}_{2}$ removal result and energy consumption [65]. The specific calculation process is complicated and time-consuming and cannot grasp the common problems of this kind of technology thoroughly. The rate-based model, although in some cases, has better accuracy results than the equilibrium model, has good predictions for the range of temperature bulges in the column [66,67], but it also has similar defects.

Compared with the previous work [65], this paper aims to develop the thermodynamic cycle, which will be constructed from the ideal cycle to the actual cycle, to evaluate the energy performance of the amine-based absorption process and the lowest regeneration heat, through an example using the benchmark solvent (MEA), shown in Figure 2. $\mathrm{COP}_{\mathrm{CO}_{2}}$, a new assessment indicator, is proposed firstly, which is used to estimate the highest efficiency of energy conversion of the CCS technologies through the comparison of the input heat and Gibbs free energy change in a thermodynamic cycle system. In addition, the second-law efficiency is applied to evaluate the thermodynamic perfection, which makes the assessment framework more complete and reasonable.

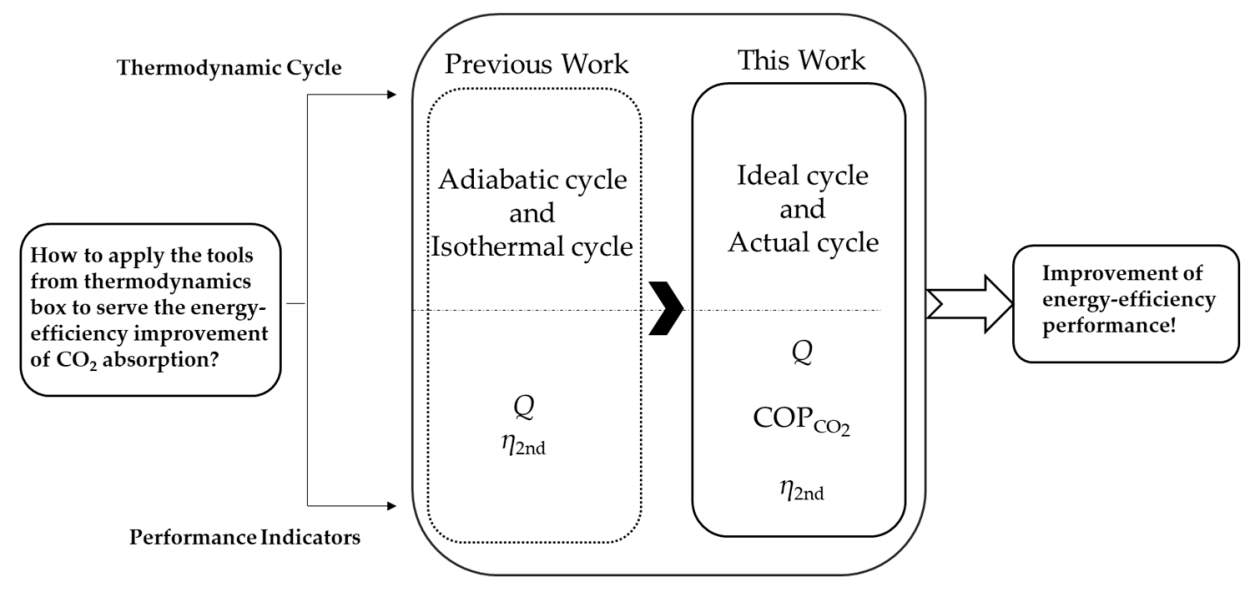

Figure 2. Comparison of thermodynamic frameworks of previous works and this work.

\section{Methodology}

\subsection{Framework of Thermodynamic Research}

Thermodynamic, as a mature, self-consistent theory, could be applied as a powerful tool to access the energy-efficient performance of an innovative energy system. Taking the most commonly applied MEA absorption as an example, the thermodynamic cycle, which is used to provide an energy profile of a complicated energy system, should be based on the properties of the MEA solution. Moreover, the absorption and desorption process should be designed reasonably, then multiple processes are connected to form a cycle. Finally, the energy-efficient analysis is performed based on the developed cycle. In addition, performance indicators, which are developed based on thermodynamics, such as $\mathrm{COP}$ or perfection, could provide valuable insights on exactly how the energy-efficient performance of such a system could be. This paper provides a new method to analyze the energy conversion efficiency of CCS technologies, as shown in Figure 3. The chemical potential of $\mathrm{CO}_{2}$ is enhanced by the input heat, changing from the low $\mathrm{CO}_{2}$ concentration state, $\mu_{1}$, to the high $\mathrm{CO}_{2}$ concentration state, $\mu_{2}$, through an amine-based absorption cycle. The ratio of the Gibbs free energy change of the $\mathrm{CO}_{2}$ gas to the input heat in the cycle means the energy conversion efficiency. 


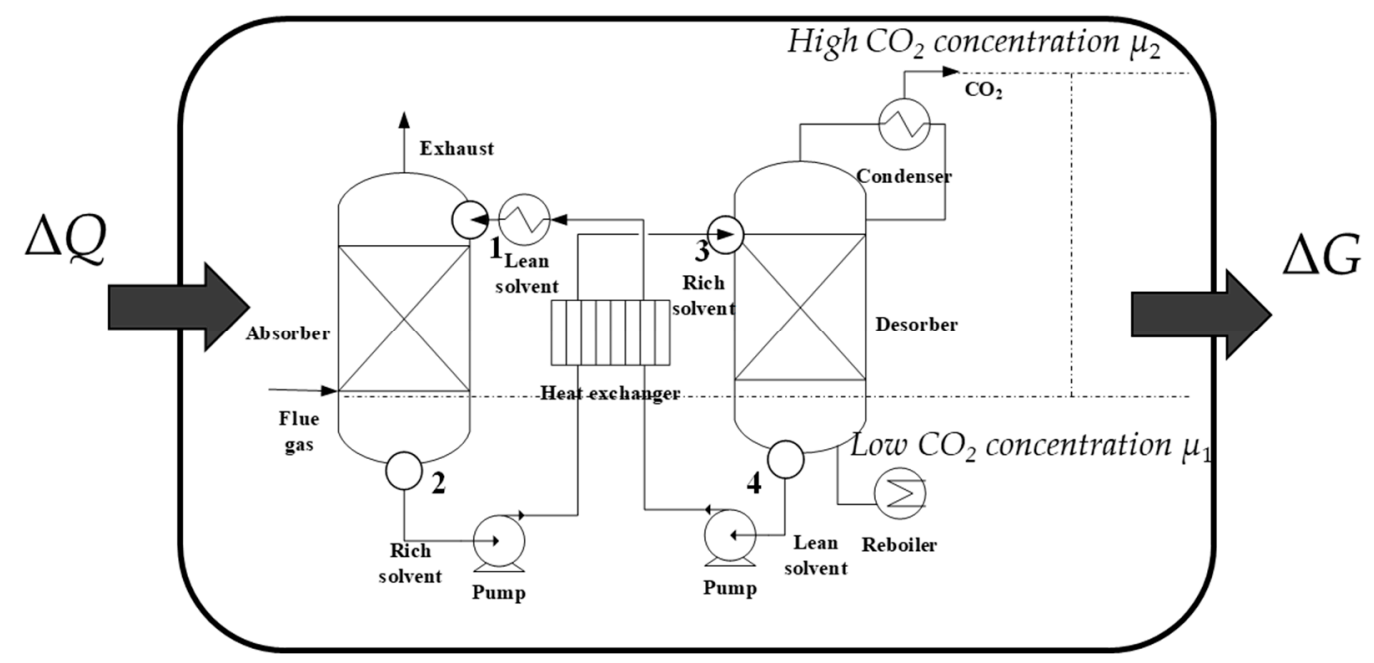

Figure 3. The new concept of energy-efficiency performance of an amine-based absorption cycle.

\subsection{Thermodynamic Cycle Construction}

\subsubsection{Thermodynamic Properties}

- Isothermal Equilibrium Curves

Vaper-liquid equilibrium (VLE) data is vital to the study of absorption and desorption processes, which determines the performance of the $\mathrm{CO}_{2}$ removal effect. Many studies have measured the VLE data of MEA solution at different temperatures and pressures. This study, according to the empirical model from [68], used a ternary aqueous solution to manifest the isothermal equilibrium curves of $30 \mathrm{wt} \%$ MEA solution. The equilibrium partial pressure of $\mathrm{CO}_{2}$ correlates with the temperature and $\mathrm{CO}_{2}$ loading, given by Equation (1):

$$
\ln P_{\mathrm{CO}_{2}}=39.3-\frac{12155}{T}-19.0 \alpha^{2}+1105 \frac{\alpha}{T}+12800 \frac{\alpha^{2}}{T},
$$

where $T$ is the temperature in $\mathrm{K} ; \mathrm{P}$ is the $\mathrm{CO}_{2}$ partial pressure in $\mathrm{Pa}$; and $\alpha$ is the $\mathrm{CO}_{2}$ loading in mol $\left(\mathrm{CO}_{2}\right) / \mathrm{mol}$ (MEA). This empirical equation could be applied for such a state, where the temperature was between 313.15 and $423.15 \mathrm{~K}$. The partial pressure of water in the stripping process was estimated by the Antoine equation corresponding to the water saturated vapor pressure, as shown in Equation (2) [69]:

$$
P_{\mathrm{H}_{2} \mathrm{O}}=x_{\mathrm{H}_{2} \mathrm{O}} \times P_{\mathrm{H}_{2} \mathrm{O}}^{*}=x_{\mathrm{H}_{2} \mathrm{O}} \times \exp \left(72.55-\frac{7207}{T}-7.139 \ln T+4.046 \times 10^{-6} \mathrm{~T}^{2}\right),
$$

where $P_{\mathrm{H}_{2} \mathrm{O}}^{*}$ is the saturated vapor pressure in $\mathrm{Pa} ; x_{\mathrm{H}_{2} \mathrm{O}}$ is the molar fraction of $30 \mathrm{wt} \%$ MEA solution; and $T$ is the temperature in $\mathrm{K}$.

- Specific Heat Capacity

In the heating process, the most relevant parameter is the specific heat capacity, $C_{p}$, in $\mathrm{kJ} / \mathrm{kg}^{\circ} \mathrm{C}$. $C_{p}$ is a function of the temperature shown in Equation (3), obtained from the Aspen Plus V 8.8 software, and using the E-NRTL model to calculate:

$$
C_{p}=10^{-7} T^{3}-10^{-5} T^{2}+0.0022 T+3.0205 .
$$

- Heat of the Absorption $\left(\Delta H_{a b s}\right)$

The heat of absorption accounts for the greatest part of energy consumption in the regeneration process. When it comes to the energy consumption, there is an assumption that the value of absorption 
heat equals desorption. $\Delta H_{a b s}\left(\mathrm{~kJ} / \mathrm{mol} \mathrm{CO} \mathrm{CO}_{2}\right)$ varies greatly with the $\mathrm{CO}_{2}$ loading change and is a correlation given by Equation (4) in [68]:

$$
\begin{aligned}
& -\Delta H_{a b s}=-13.67+0.308 T(\alpha \leq 0.46) \\
& -\Delta H_{a b s}=-127.13+246.65 \alpha+1.02 T-1.54 \alpha T(0.46 \leq \alpha \leq 0.66) . \\
& -\Delta H_{a b s}=35.66(0.66 \leq \alpha)
\end{aligned}
$$

\subsubsection{Processes}

A classical chemical absorption process should be divided into a four-step process, including absorption, pre-heating, desorption, and cooling. Firstly, the handled flue gas gets into the capture system, and is absorbed by MEA solvent in the absorber (1-2). Then, the rich solvent (high $\mathrm{CO}_{2}$-loading) will be pre-heated by the heater (2-3). Then, the rich solvent enters the desorber to release $\mathrm{CO}_{2}$, where plenty of steam is produced by the reboiler (3-4). Finally, the lean solvent (low $\mathrm{CO}_{2}$-loading) is cooled to the initial temperature (4-1).

\subsubsection{Construction from the Ideal Cycle to the Actual Cycle}

An ideal four-step chemical amine-based cycle is drawn in an isothermal equilibrium curves diagram as given in Figure 4. Before the configuration, there are some assumptions to simplify the ideal cycle:

1. The absorption and the desorption are set to an isothermal process.

2. During the pre-heating and cooling process, the $\mathrm{CO}_{2}$ loading remains unchanged, that is, no $\mathrm{CO}_{2}$ desorption occurs.

3. The absorption and the desorption process are in a gas-liquid equilibrium state.

4. All kinds of heat loss in the cycle are not considered.

5. The solution does not react with other types of gases in the flue gas except $\mathrm{CO}_{2}$, and the flue gas is assumed to be an ideal gas.

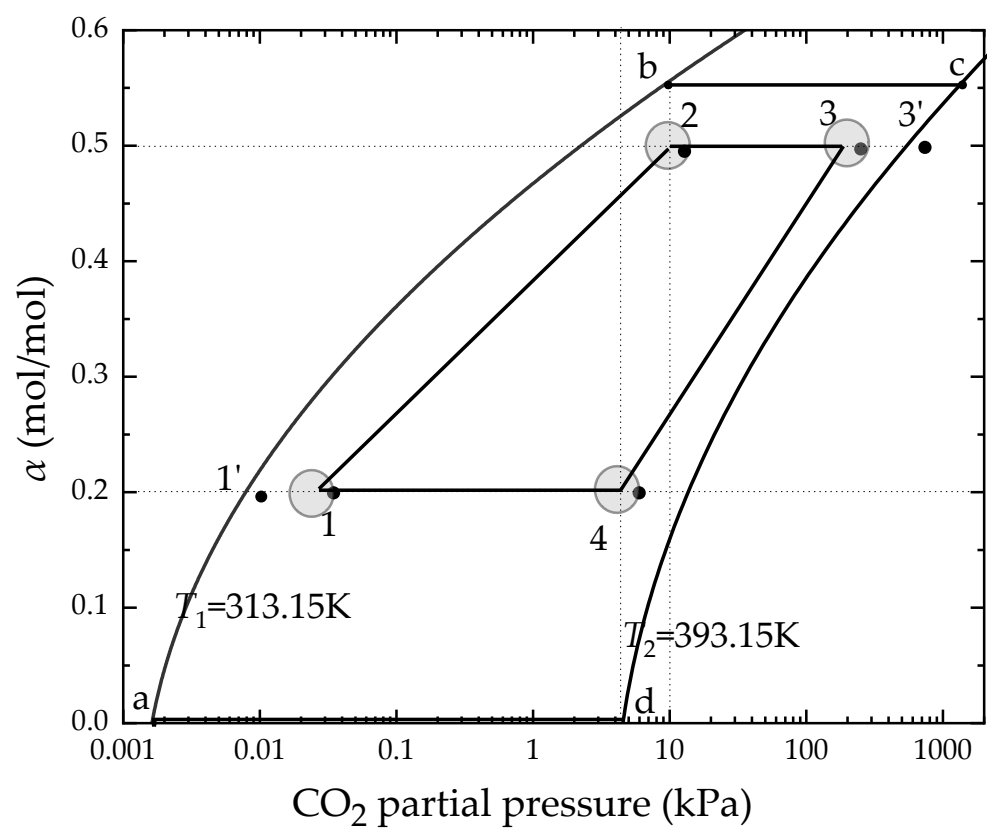

Figure 4. The state points of thermodynamic cycle construction in MEA solution.

Based on the above assumptions, the ideal four-step chemical amine-based cycle was established as follows: 
Step 1(a-b): The process is an isothermal absorption process, $\mathrm{CO}_{2}$ is absorbed, and the absorption process can be regarded as slowly reaching the equilibrium state, point $b$, along the gas-liquid isothermal equilibrium line. The determination of the state point, $b$, is determined by the concentration of $\mathrm{CO}_{2}$ in the flue gas, that is, by the carbon source. For example, the flue gas pressure is set at an atmospheric pressure of $101 \mathrm{kPa}$ and the $\mathrm{CO}_{2}$ concentration is $10 \%$, then the state point $\mathrm{b}$ corresponds to a $\mathrm{CO}_{2}$ partial pressure of $10.1 \mathrm{kPa}$, which is according to Dalton's partial pressure law.

Step 2(b-c): The process is a pre-heating process in which the rich solvent is heated up by the heater, and no $\mathrm{CO}_{2}$ desorption occurs, that is, $\mathrm{CO}_{2}$ loading remains unchanged.

Step 3(c-d): The desorption process, in which a large amount of water vapor is generated by the reboiler in the process, resulting in a decrease in the partial pressure of $\mathrm{CO}_{2}$, and the $\mathrm{CO}_{2}$ in the liquid phase is desorbed along with the isothermal equilibrium line.

Step $4(\mathrm{~d}-\mathrm{a})$ : The cooling process, in which the lean solvent is cooled by the condenser, returning to the state point $a$, and starting a new cycle.

As shown in Figure 3, the ideal cycle implies the reaction time is infinitely long and the performance of the absorbent is too ideal. At the same time, it indicates the ideal energy efficiency that the actual cycle can never reach, which is also not easy to compare with other models. Therefore, combined with the actual performance of the MEA solution and other practical constraints, the lean and rich solvent loading were set to $0.2 \mathrm{~mol} / \mathrm{mol}$ and $0.50 \mathrm{~mol} / \mathrm{mol}$, respectively. Within the constraints of the carbon source and carbon sink, this ensures the state points 2 and 4 , the driving force, $R_{a b s}$ and $R_{\text {des }}$, and a condition parameter will be used to describe the how close the actual partial pressure is with the equilibrium partial pressure in the absorption and desorption process, which are defined as Equation (5) and Equation (6):

$$
\begin{aligned}
& R_{a b s}=\frac{P_{1}}{P_{1}^{\prime}}, \\
& R_{\text {des }}=\frac{P_{3}^{\prime}}{P_{3}},
\end{aligned}
$$

where $R_{a b s}$ and $R_{\text {des }}$ are the partial pressure ratios for absorption and desorption; $P_{1}^{\prime}$ and $P_{3}^{\prime}$ are the equilibrium $\mathrm{CO}_{2}$ partial pressure of lean and rich solvent; and $P_{1}$ and $P_{3}$ are the $\mathrm{CO}_{2}$ partial pressure of the inlet of the absorber and the inlet of the desorber.

Then, a new four-step chemical amine-based cycle, 1-2-3-4-1, a close match with the actual cycle, is formed.

\subsection{Performance Indicators}

Thermodynamics has proper analysis tools for efficiency assessment and improvement. The intuitive energy consumption, energy conversion efficiency, and the second-law efficiency are shown in Table 3.

\begin{tabular}{|c|c|c|}
\hline Rege & $\mathrm{COP}_{\mathrm{CO}_{2}}$ & The Second-Law Efficiency \\
\hline$Q_{r e}=Q_{\text {sens }}+Q_{a b s}+Q_{v a p}$ & $C O P_{\mathrm{CO}_{2}}=\frac{\left(\Delta G^{\prime}+\Delta H_{1}\right)+\left(W_{\min }+\Delta H_{2}\right)}{W_{\min }+\Delta H_{2}}$ & $\eta_{2 n d}=\frac{W_{\min }}{W_{P}+Q_{r e}\left(1-\frac{T_{0}}{T_{H}}\right)-Q_{c}\left(1-\frac{T_{0}}{T_{L}}\right)}$ \\
\hline $\begin{array}{l}\text { The intuitive energy consumption } \\
\text { of absorption CCS. }\end{array}$ & $\begin{array}{c}\text { The potential capacity of energy } \\
\text { conversion of CCS; the highest } \\
\text { energy efficiency. }\end{array}$ & $\begin{array}{c}\text { The develop level of existing CCS } \\
\text { technology compared to ideal } \\
\text { situation. }\end{array}$ \\
\hline
\end{tabular}

Table 3. Thermodynamic evaluation parameters for CCS.

\subsubsection{Regeneration Heat}

Regeneration heat is the most important part of the chemical absorption method. The total regeneration heat, $Q_{\text {re, }}$ can be divided into three parts [70]: Sensible heat, $Q_{\text {sens, }}$, for solution heating; 
absorption heat, $Q_{\mathrm{abs}}$, for the reaction process, and latent heat, $Q_{\mathrm{vap}}$, for generating stripping steam as shown in Equation (7) to Equation (11):

$$
\begin{gathered}
Q_{r e}=Q_{\text {sens }}+Q_{a b s}+Q_{v a p}, \\
Q_{\text {sens }}=\frac{m_{s} \int_{T_{\text {lean, end }}}^{T_{3}} C_{p} d T}{q}, \\
m_{s}=M_{\text {sol }} * \frac{\eta X_{\mathrm{CO}_{2}}}{\Delta \alpha x_{\text {solv }}} * F,
\end{gathered}
$$

where $m_{\mathrm{S}}$ is the mass flow rate of the solution in $\mathrm{kg} / \mathrm{sec} ; T_{\text {lean,end }}$ is the temperature of the lean solvent entering the desorber in $\mathrm{K} ; q$ is the mass flow rate of captured $\mathrm{CO}_{2}$ in $\mathrm{kg} / \mathrm{sec} ; \eta$ is the capture rate; $\mathrm{X}_{\mathrm{CO}_{2}}$ is the concentration of $\mathrm{CO}_{2}$ in the flue gas; $F$ is the molar flow rate of the flue gas in $\mathrm{mol} / \mathrm{sec} ; x_{\text {solv }}$ is the molar fraction of the solvent; and $M_{\text {sol }}$ is the molar mass of the solution; $\Delta \alpha$ is the $\mathrm{CO}_{2}$ capacity in $\mathrm{mol} / \mathrm{mol}$.

$$
Q_{a b s}=\frac{\int_{\alpha_{3}}^{\alpha_{4}} \Delta H_{a b s} d \alpha}{M_{\mathrm{CO}_{2}}},
$$

where $\alpha$ is the $\mathrm{CO}_{2}$ loading of the corresponding states in mol/mol; $\mathrm{M}_{\mathrm{CO}_{2}}$ is the molar mass of $\mathrm{CO}_{2}$.

$$
Q_{\text {vap }}=H_{\text {vap }} * \frac{x_{\mathrm{H}_{2} \mathrm{O}} * P_{\mathrm{H}_{2} \mathrm{O}}^{*}}{P_{\mathrm{CO}_{2}}^{*}} * R_{\text {des }} * \frac{1}{M_{\mathrm{CO}_{2}}},
$$

where $P_{\mathrm{H}_{2} \mathrm{O}}^{*}$ and $P_{\mathrm{CO}_{2}}^{*}$ are the equilibrium pressure of $\mathrm{H}_{2} \mathrm{O}$ and $\mathrm{CO}_{2}$ in the desorber; $x_{\mathrm{H}_{2} \mathrm{O}}$ is the molar fraction of water; and $H_{\text {vap }}$ is the latent heat of vaporization of water, $H_{\text {vap }}=41 \mathrm{~kJ} / \mathrm{mol}$.

\subsection{2. $\mathrm{COP}_{\mathrm{CO}_{2}}$}

The concept of COP was first used in refrigeration and heat pumps, which represents the ratio of the released cooling (heat) of the chiller (heat pump) to its net input energy. Using COP for energy efficiency analysis of refrigeration (heat pump) units, it can intuitively describe the energy conversion efficiency, and has a clear meaning in improving energy efficiency and reducing energy consumption. For this new cycle system that brings the Gibbs free energy change of gas caused by the driving work or heat, the traditional thermodynamic assessment indicators cannot evaluate its effect in energy conversion efficiency well. Then, based on the meaning of income and cost, expanding its application to CCS technologies is a key point of this paper. Then, $\mathrm{COP}_{\mathrm{CO}_{2}}$, a new assessment parameter, is introduced from the meaning and expression. In the beginning, the environmental model proposed by J. Szargut [71] should be introduced to calculate the chemical exergy of the substance. For example, at an ambient temperature of $298.15 \mathrm{~K}$, an ambient pressure of $\mathrm{P}=0.101325 \mathrm{MPa}$, and a $\mathrm{CO}_{2}$ concentration of $0.0004 \%$ in the ambient atmosphere, as long as the gas has a higher concentration or temperature, thus, it possesses chemical exergy. Figure 5 shows the description of the physical meaning of $\mathrm{COP}_{\mathrm{CO}_{2}}$. Based on the carbon pump theory [72], a feed gas with a low concentration of $\mathrm{CO}_{2}$, which can be a combustion flue gas, through the carbon pump turns into a high $\mathrm{CO}_{2}$ concentration product gas, gaining an increase of the chemical energy. The ratio of the increase in chemical energy to the input heat is the value of $\mathrm{COP}_{\mathrm{CO}_{2}}$. The expression of $\mathrm{COP}_{\mathrm{CO}_{2}}$ is shown in Equation (12) and Equation (13) is the fractional molar Gibbs free energy of each component of the ideal gas:

$$
\begin{gathered}
C O P_{\mathrm{CO}_{2}}=\frac{\left(\Delta G^{\prime}+\Delta H_{1}\right)+\left(W_{\min }+\Delta H_{2}\right)}{W_{\min }+\Delta H_{2}}, \\
\frac{\partial G}{\partial n_{i}}=R T \ln \left(\frac{p_{i}}{p}\right)+G_{i}^{0}
\end{gathered}
$$


where $\Delta G^{\prime}$ is the Gibbs free energy change from the standard state, $G$, to a middle state, $G^{\prime}$, which is an isothermal and isobaric process; $\Delta H_{1}$ is the metamorphosis from state $G^{\prime}$ to state $G_{1}$, which is an isoconcentration process; $W_{\min }$ is the minimum separation work and has been discussed in many references, such as [61,62]; here $W_{\min }=G_{1}^{\prime}-G_{1}$; and $\Delta H_{2}$ is the metamorphosis from state $G_{1}$ to state $G_{1}^{\prime}$, which is an isothermal and isobaric process too.

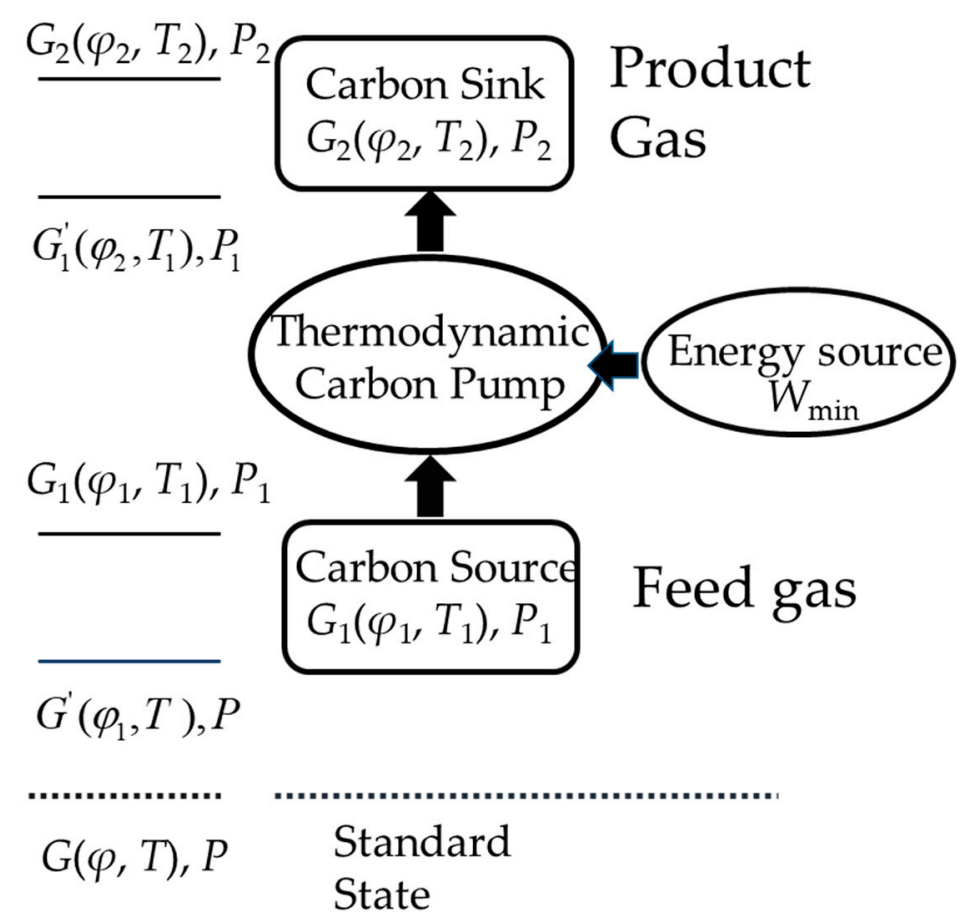

Figure 5. Concept and expression of $\mathrm{COP}_{\mathrm{CO}_{2}}$.

\subsubsection{The Second-Law Efficiency}

The second-law efficiency is the ratio of the minimum separation work, $W_{\min }$, to the exergy of the system of the actual process as shown in Equation. (14), which has a certain guiding significance to engineering:

$$
\eta_{2 n d}=\frac{W_{\min }}{W_{P}+Q_{r e}\left(1-\frac{T_{0}}{T_{H}}\right)-Q_{c}\left(1-\frac{T_{0}}{T_{L}}\right)}
$$

where $W_{\mathrm{P}}$ is the electric energy consumed by the carbon capture process, mainly pump work, which accounts for a small proportion compared with the regenerative heat; $Q_{\mathrm{c}}$ is the heat required for cooling, whose value could approximately equal $Q_{\text {sens }}+Q_{\text {vap }}$, provided by cooling water; $T_{0}$ is the environment temperature, $298.15 \mathrm{~K} ; T_{\mathrm{H}}$ is the heat source temperature set to the desorption temperature; and $T_{\mathrm{L}}$ is the cold source temperature, where the cooling water temperature is usually equal to $T_{0}$.

\section{Results and Discussion}

Based on the thermodynamic cycle constructed in Section 2.2, the energy performance was analyzed with the representative parameters, and the regeneration heat was compared with the equilibrium model, the detailed information of which can be seen in Table 4 . The following cases are based on $R_{\mathrm{abs}}=100$ and the pinch temperature of the heat exchanger was $10 \mathrm{~K}$. 
Table 4. Information of the equilibrium model.

\begin{tabular}{cc}
\hline Design Parameters & Value \\
\hline Flow of gas $(\mathrm{L} / \mathrm{min})$ & 500 \\
Mass fraction of MEA $(\%)$ & 30 \\
Temperature of gas $\left({ }^{\circ} \mathrm{C}\right)$ & 40 \\
Number of stages & 20 \\
Pinch temperature of heat exchanger $(\mathrm{K})$ & 10 \\
Property calculation method & E-NRTL \\
Mole fraction of $\mathrm{CO}_{2}(\%)$ & 8 to16 \\
\hline
\end{tabular}

\subsection{Effect of the Ratio of Liquid:Gas (L/G)}

The liquid:gas ratio is an important parameter for the absorption effect of the absorption process and the energy consumption required for the desorption process. It is generally believed that the absorption effect is better when the liquid:gas ratio is larger, but at the same time, the energy consumption of the solution regeneration process will increase. It is extremely important to select a reasonable liquid:gas ratio for the carbon capture process. Figures 6 and 7 show the effect of L/G for the thermodynamic cycle and equilibrium model. L/G varies from 2.2 to 3, and both thermodynamic cycle and equilibrium model show a similar trend. $Q_{\text {sens }}$ and $Q_{\text {vap }}$ increase lightly and $Q_{\text {abs }}$ decreases, then the best $\mathrm{L} / \mathrm{G}$ is in the actual carbon capture process. The value ranges from 2.84 to $2.82 \mathrm{GJ} / \mathrm{t}$, and then it stars to increase up to $2.88 \mathrm{GJ} / \mathrm{t}$ when $\mathrm{L} / \mathrm{G}$ varies from 2.2 to 3 . The difference is greater in the equilibrium model, which ranges from 4.15 to $3.99 \mathrm{GJ} / \mathrm{t}$, and then to $4.22 \mathrm{GJ} / \mathrm{t}$.

The effect to $\mathrm{W}_{\mathrm{min}}, \mathrm{COP}_{\mathrm{CO}_{2}}$, and $\eta_{2 \text { nd }}$ is acting on the change of the capture ratio. With the increase of $L / G$, the capture ratio should be higher, then causes the $W_{\min }$ to increase, which increases from 150.0 to $172.2 \mathrm{~kJ} / \mathrm{kg}$. The $\mathrm{COP}_{\mathrm{CO}_{2}}$, however, representing the energy conversion efficiency, decreases from 2.54 to 2.40 and means it is harder for work or heat transformation to the chemical energy of $\mathrm{CO}_{2}$ with the $\mathrm{CO}_{2}$ removal ratio increasing. In another point, $\eta_{2 \text { nd }}$ rises from $23.4 \%$ to $26.4 \%$ with $W_{\text {min }}$ increasing, which means the room for improvement of the energy performance of the cycle becomes less. There is another factor that should be taken into account, which is that the $\mathrm{L} / \mathrm{G}$ increase will bring extra pump work and needs an increase in some degree in the actual situation, which is also bad for a hole capture system.

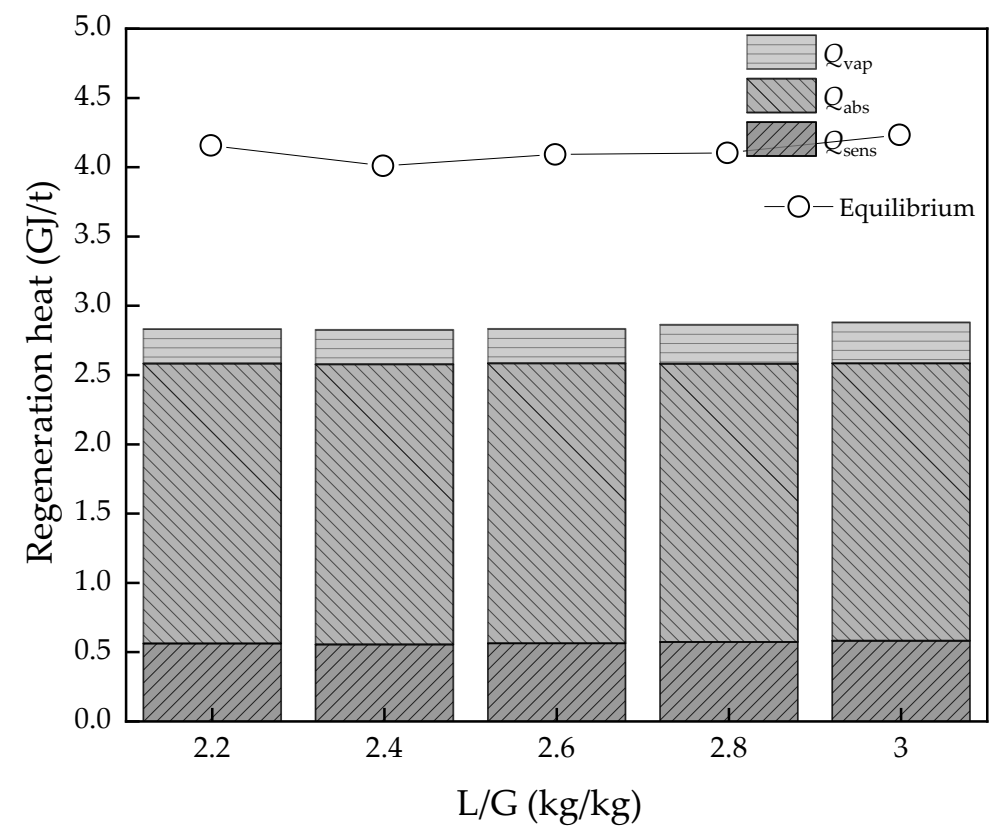

Figure 6. The regeneration heat changes with $L / G$ value variation. 


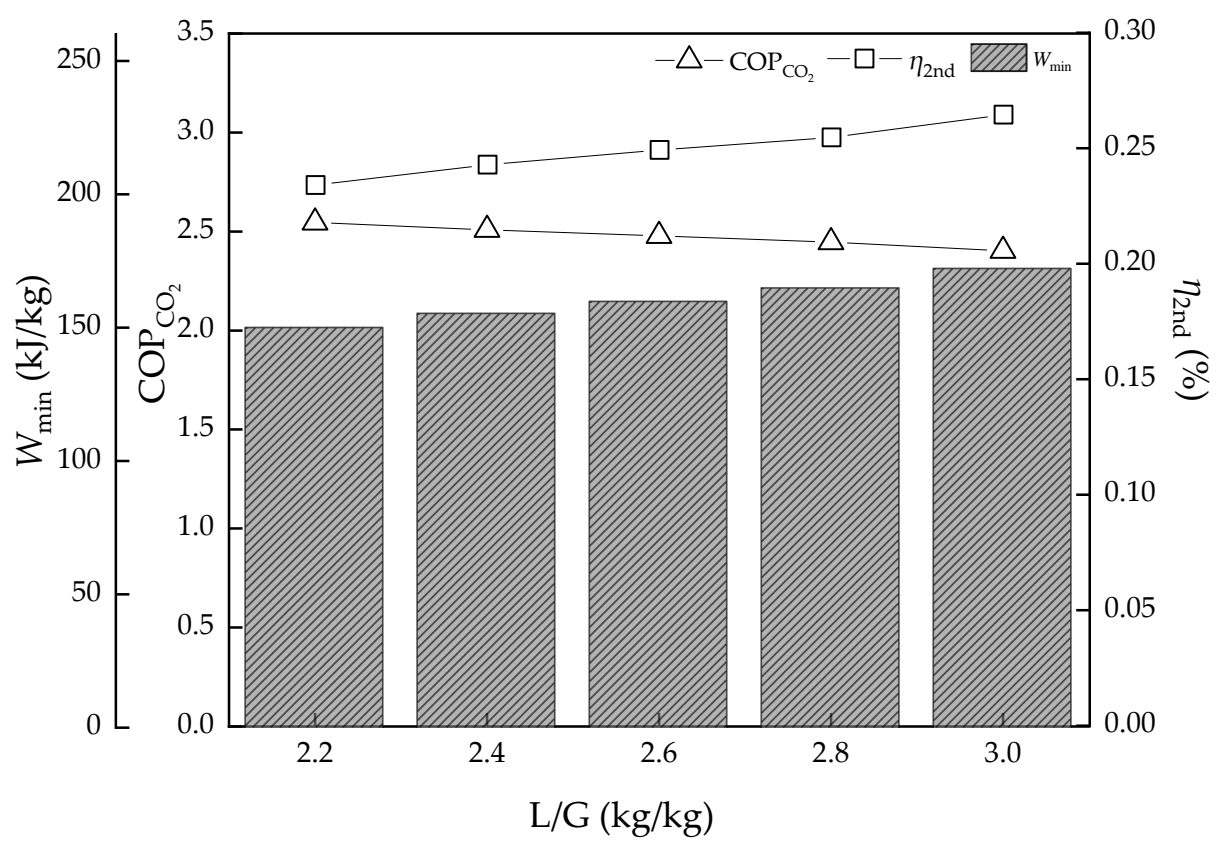

Figure 7. The energy efficiency performance with L/G value variation.

\subsection{Effect of $\mathrm{CO}_{2}$ Concentration of $\mathrm{Gas}$}

The concentration of $\mathrm{CO}_{2}$ in the flue gas varies, especially in different power plants which use different coal and operating equipment or different industrial senses. This is a key parameter in the input of the CCS system and Figures 8 and 9 show the effect of variable $\mathrm{CO}_{2}$ concentrations of gas from $8 \%$ to $16 \%$, which is suitable for the component of flue gas of coal-fired power plants.

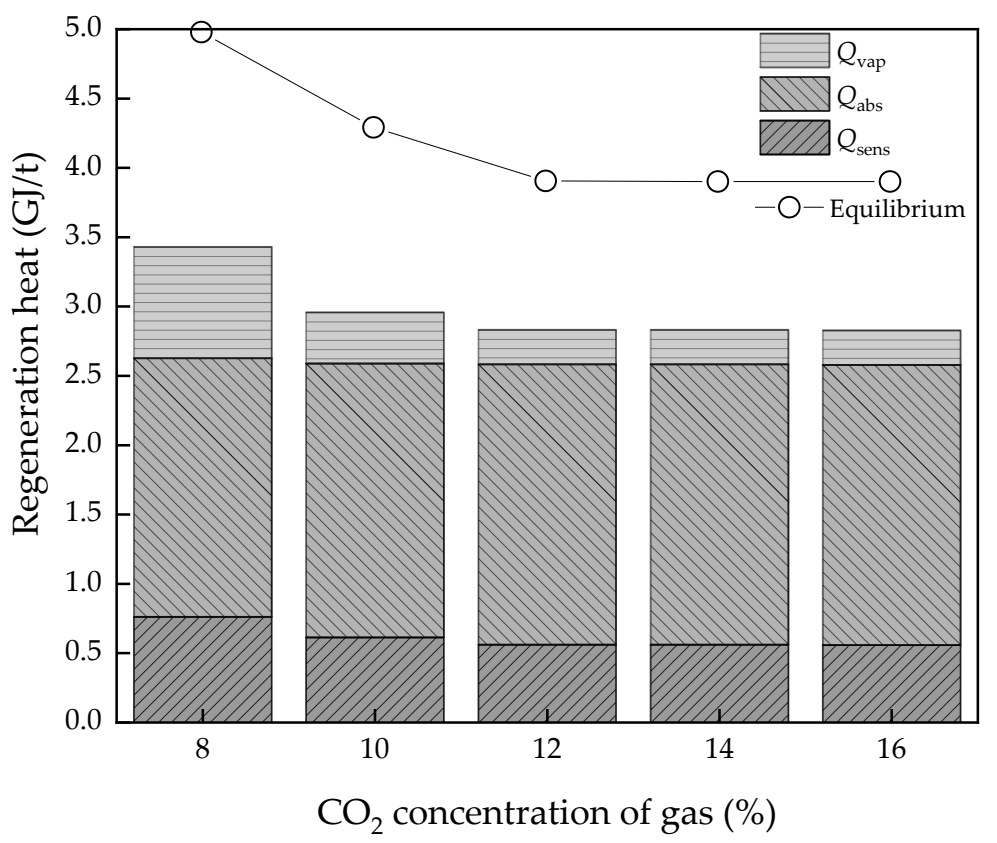

Figure 8. The regeneration heat changes with the $\mathrm{CO}_{2}$ concentration variation.

At low concentrations, the energy consumption is apparently high both in the thermodynamic cycle and equilibrium model at 3.43 and $4.97 \mathrm{GJ} / \mathrm{t}$, respectively, which may be similar to the effect a high $\mathrm{L} / \mathrm{G}$ brings. Then, as the $\mathrm{CO}_{2}$ concentration increases, the regeneration heat declines sharply. However, it has a limitation as when the concentration is higher than the absorption capacity for 
a certain $\mathrm{L} / \mathrm{G}$ value, the regeneration heat will not continue to decline. The lowest value is 2.82 and $3.89 \mathrm{GJ} / \mathrm{t}$, respectively. On the other hand, when it comes to the energy conversion efficiency, the higher $\mathrm{CO}_{2}$ concentration is good news. The $W_{\min }$ decreases from 201.1 to $128.2 \mathrm{~kJ} / \mathrm{kg}$ continuously and $\mathrm{COP}_{\mathrm{CO}_{2}}$ continuously increase to 2.80 . The $\eta_{2 \text { nd }}$ has a similar trend with $W_{\min }$, which decreases from $27.8 \%$ to $20.0 \%$, with lower values indicating more room for improvement of energy performance.

In summary, the higher the $\mathrm{CO}_{2}$ concentration, the higher the result of energy conversion. However, the actual solvent could not achieve such an ideal level and the existing technological process of absorption is also a limitation, which hinders the energy performance.

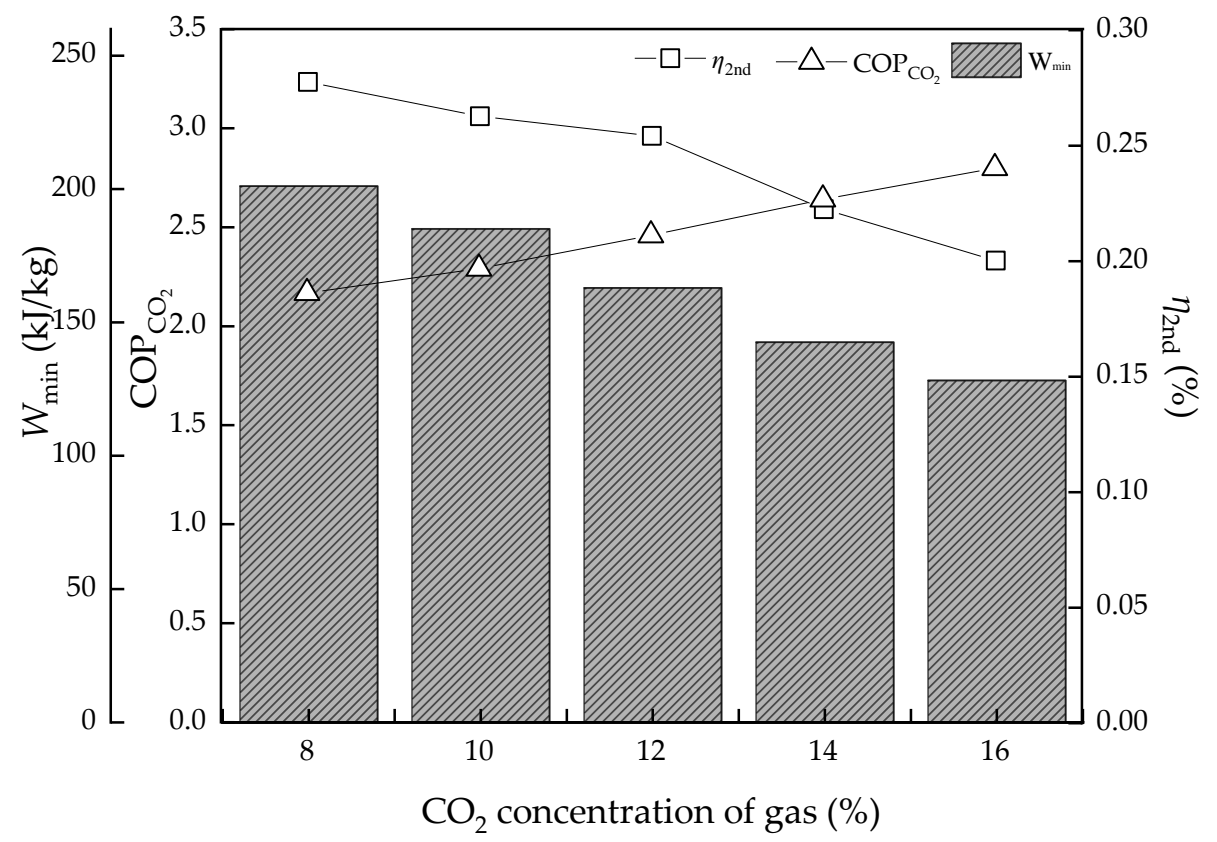

Figure 9. The energy efficiency performance with the $\mathrm{CO}_{2}$ concentration variation.

\subsection{Effect of Desorption Temperature}

The desorption temperature is an important factor of solvent properties and operating conditions. Figures 10 and 11 show the result of the energy performance with different desorption temperatures. Attention should be given to the desorption temperature as the final stage temperature in the equilibrium model. The $Q_{\text {sens }}$ and $Q_{\text {abs }}$ have a slight increase, while the $Q_{\text {vap }}$ decreases due to the $P_{\mathrm{CO}_{2}}$ growth. Then, the regeneration heat of the thermodynamic method and equilibrium model both have a growth trend and the equilibrium model is more obvious from 3.75 to $4.32 \mathrm{GJ} / \mathrm{t}$, while the thermodynamic cycle is from 2.82 to $2.85 \mathrm{GJ} / \mathrm{t}$ in the ideal condition. The $\mathrm{COP}_{\mathrm{CO}_{2}}$ and $\eta_{2 \text { nd }}$ both have a decreasing trend, but it is not obvious, from $2.48 \%$ to $2.43 \%$ and from $26.1 \%$ to $24.4 \%$, respectively. Compared to the effect of the thermodynamic properties of MEA solvents, such as thermal degradation, the temperature change of desorption has little influence on the energy performance in ideal conditions, but in actual sense, the heat loss of every part will be greater. 


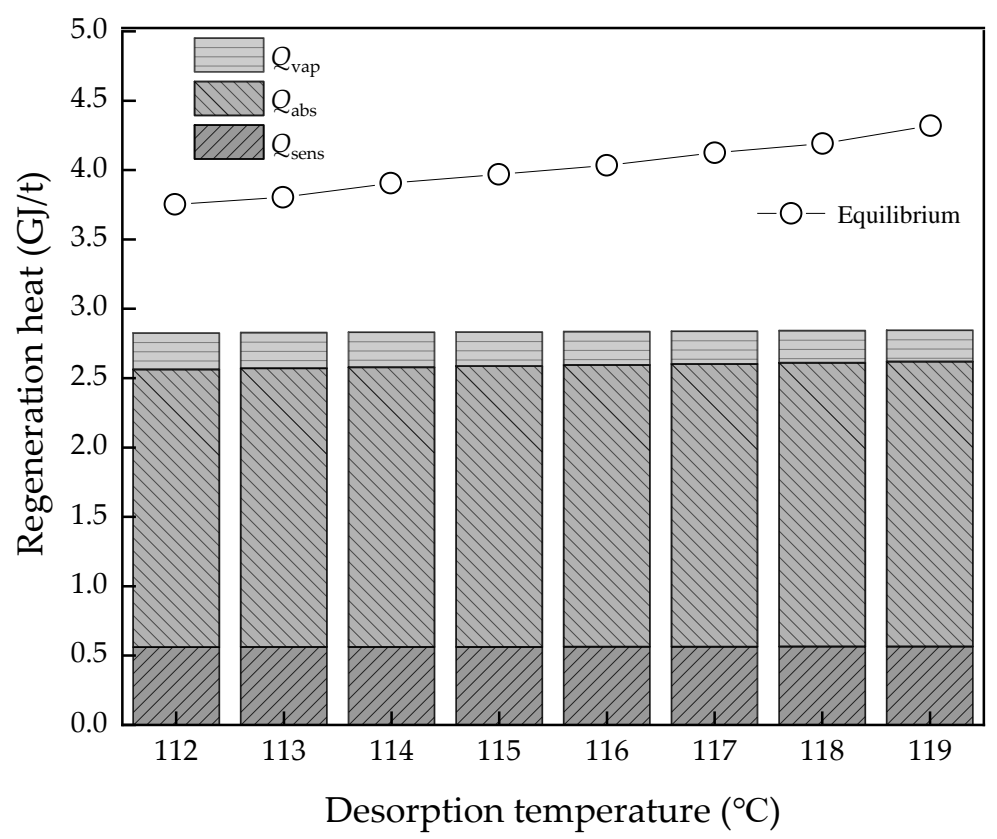

Figure 10. The regeneration heat changes with the desorption temperature variation.

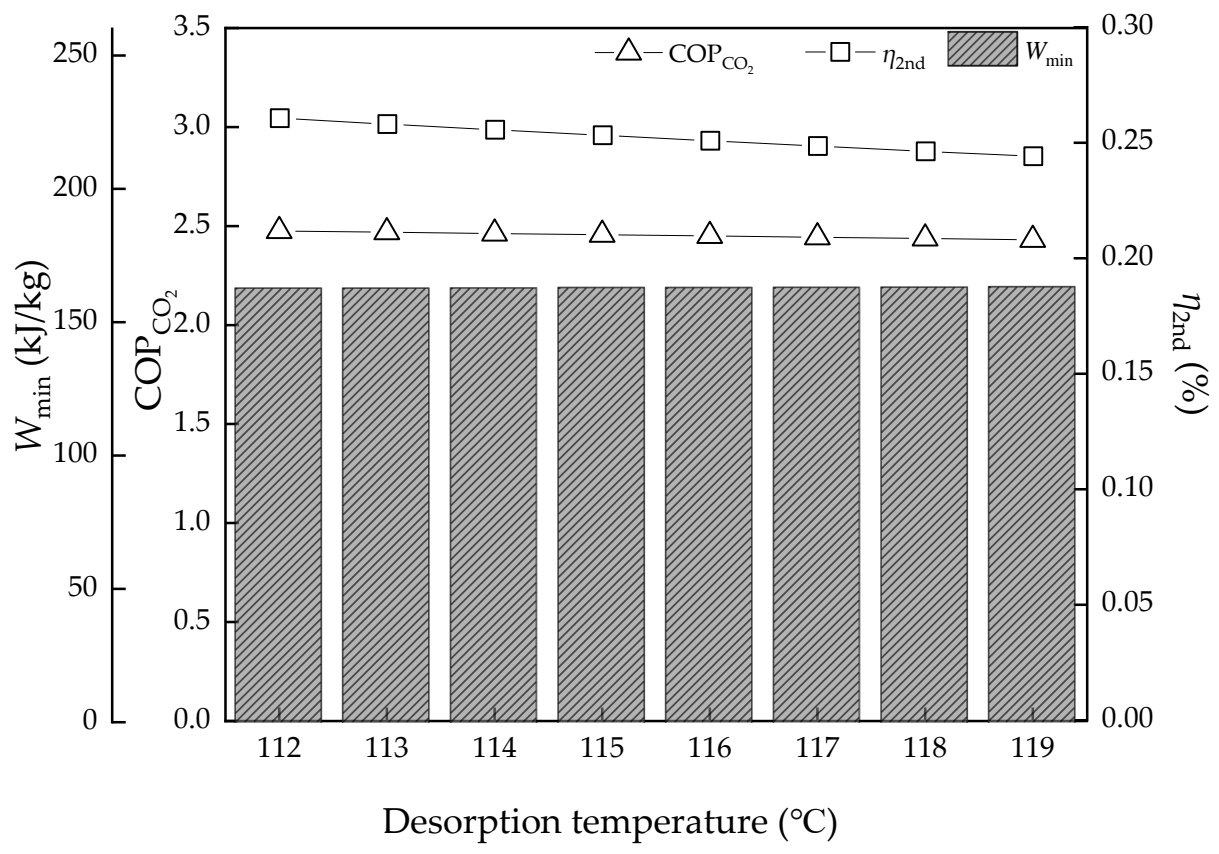

Figure 11. The energy efficiency performance with the desorption temperature variation.

\subsection{Effect of $R_{\text {des }}$ and Pinch Temperature of the Heat Exchanger}

The desorption driving force, $R_{\text {des }}$, is the degree of closeness of the actual process to the ideal thermodynamic equilibrium process. The ideal condition $\left(R_{\text {des }}=1\right)$ has the lowest energy consumption of $Q_{\text {vap }}$, which was discussed above. Figure 12 shows a validation of the desorption temperature, $T_{3}$, with different $R_{\text {des }}$. The $Q_{\text {vap }}$ grows rapidly and the gap is greater the more the $R_{\text {des }}$ value increases. The difference of $Q_{\text {vap }}$ changes from 1.31 to $1.13 \mathrm{GJ} / \mathrm{t}\left(R_{\text {des }}=5\right)$, while from 0.263 to $0.227 \mathrm{GJ} / \mathrm{t}\left(R_{\text {des }}=\right.$ $1)$. The effect of the desorption temperature is magnified, but the energy consumption is also higher. Though it is limited by the existing technical means and specific operating conditions, the lower $R_{\mathrm{des}}$ has better energy performance. 


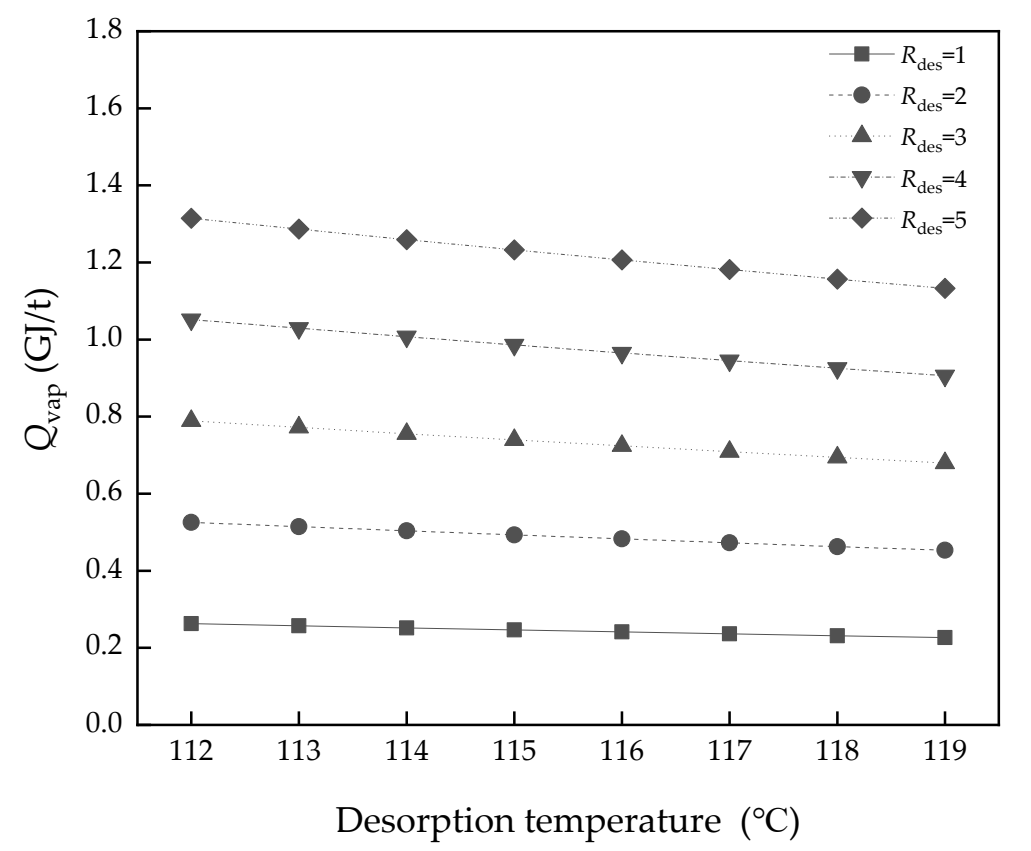

Figure 12. The difference of $Q_{\text {vap }}$ with desorption temperature variation in different $R_{\text {des. }}$.

The pinch temperature of the heat exchanger, $\Delta T_{\text {heat-ex, }}$, is a parameter involving the cost of heat exchanger equipment and the placement space. Certainly, better performance of the heat exchanger brings lower $Q_{\text {sens }}$ and lower heat loss. As shown in Figure 13, when $\mathrm{L} / \mathrm{G}=2.4, \Delta T_{\text {heat-ex }}$ changes from 5 to $25 \mathrm{~K}$, and the $Q_{\text {sens }}$ climbs from 0.28 to $1.38 \mathrm{GJ} / \mathrm{t}$, but it is a compromise, combined with others factor to decide.

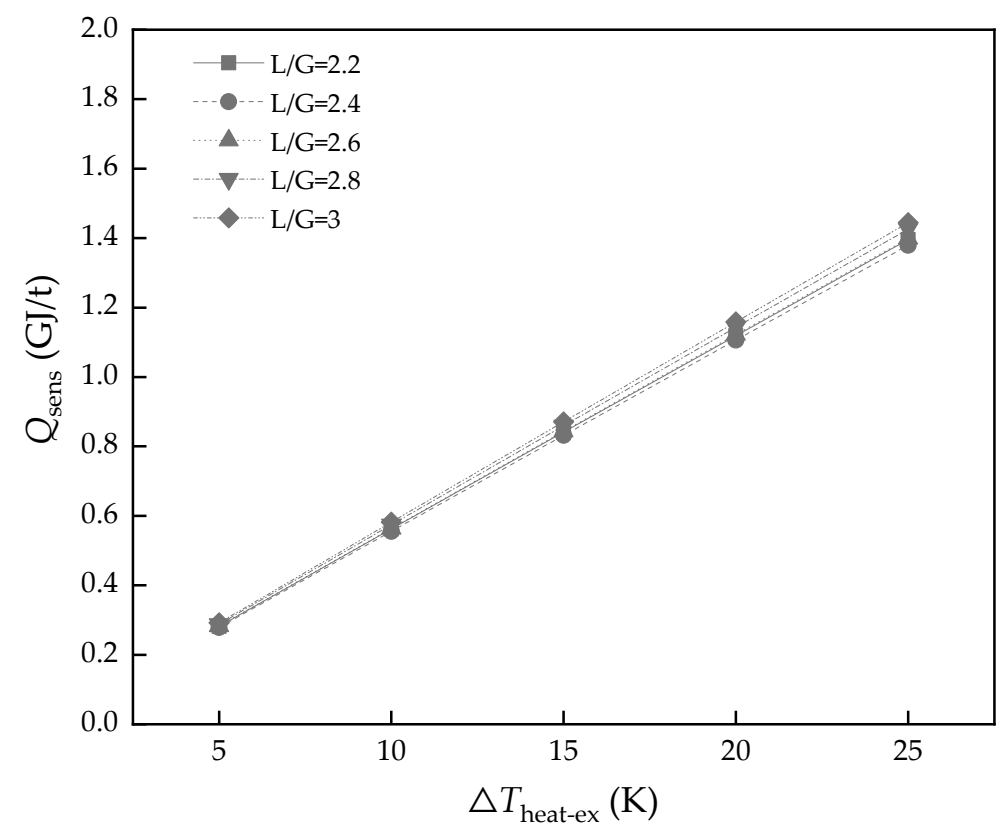

Figure 13. The energy consumption of $Q_{\text {sens }}$ with different heat exchanger performances.

\section{Conclusions}

This paper aimed to develop a kind of thermodynamic cycle for amine-based chemical absorption of CCS to assess the lowest regeneration heat and energy efficiency. Based on the cycle, three thermodynamic assessment indicators were used to evaluate the energy performance and the regeneration heat was compared with the equilibrium model. The following results can be concluded: 
1. A new indicator, $\mathrm{COP}_{\mathrm{CO}_{2}}$, was proposed firstly, which would be integrated into the current assessment framework of $\mathrm{CO}_{2}$ absorption systems to be more complete.

2. As for $30 \mathrm{wt} \%$ MEA solvent, the lowest regeneration heat was $2.82 \mathrm{GJ} / \mathrm{t}$ when $R_{\text {des }}=1$ and $\Delta T_{\text {heat-ex }}=10 \mathrm{~K}$ and the highest energy conversion efficiency was 2.80 in these cases.

3. The $\mathrm{L} / \mathrm{G}$ had the best value, as too high and too low are both bad for energy consumption of regeneration heat. However, for potential energy efficiency improvement, the lower the $L / G$ value, the better, on the assumption that the solvent could achieve the goal of the removal rate. As for the $\mathrm{CO}_{2}$ concentration of flue gas, the higher the value, the better energy performance and efficiency. However, real performance is limited by the solvent properties, which may not achieve the ideal conditions; the lowest regeneration heat was about 2.82 and $3.89 \mathrm{GJ} / \mathrm{t}$, respectively, while the $\mathrm{COP}_{\mathrm{CO}_{2}}$ continued to increase. The desorption temperature was not a sensitive parameter to energy performance in an ideal condition. However, in the actual situation, the higher the temperature, the higher the heat loss.

4. The operating parameters, $R_{\text {des }}$ and $\Delta T_{\text {heating-ex, }}$ were a compromise between cost and performance. The better performance of the heat exchanger will bring a lot of energy saving in $Q_{\text {sens, }}$, which decreased from 1.38 to $0.28 \mathrm{GJ} / \mathrm{t}$ when $\Delta T_{\text {heating-ex }}$ varied from 25 to $5 \mathrm{~K}$ in $\mathrm{L} / \mathrm{G}=2.4$.

Finally, this thermodynamic cycle is expected to be used as an analysis tool for the energy efficiency performance of amine-based chemical absorption; however, more aspects, like thermal degradation, viscosity, and so on, should be considered and need further study.

Author Contributions: Conceptualization, Y.X.; Data curation, S.L.; Methodology, L.Z. and X.Y.; Software, J.F. and Y.L.; Writing — original draft, Y.X.; Writing—review amd editing, S.D.

Funding: This research was funded by China National Natural Science Funds, grant number 51876134, by Research Plan of Science and Technology of Tianjin City, grant number 18YDYGHZ00090 and by Tianjin Talent Development Special Support Program for High-Level Innovation and Entrepreneurship team.

Conflicts of Interest: The authors declare no conflict of interest.

\section{Nomenclature}

$\begin{array}{llll}\text { Symbols } & & \text { sol } & \text { MEA solution } \\ P & \text { Pressure } & \text { Greek letters } & \\ T & \text { Temperature } & \alpha & \mathrm{CO}_{2} \text { loading } \\ \Delta H_{\mathrm{abs}} & \text { Heat of } \mathrm{CO}_{2} \text { absorption } & \Delta \alpha & \mathrm{CO}_{2} \text { capacity } \\ \mathrm{H}_{\mathrm{vap}} & \text { Heat of water evaporation } & \eta_{2 \mathrm{nd}} & \text { Second law efficiency } \\ \mathrm{C}_{\mathrm{p}} & \text { Specific heat of solution } & \eta & \text { Capture rate } \\ Q & \text { Energy consumption } & \text { Acronym } & \\ x & \text { Molar fraction } & \mathrm{CCS} & \text { Carbon capture } \\ R & \text { Partial pressure ratio } & \mathrm{L} / \mathrm{G} & \text { Ratio of liquid-gas } \\ M & \text { Molar mass } & \mathrm{ILS} & \text { Ionic liquids } \\ \mathrm{X}_{\mathrm{CO}} & \text { Concentration of } \mathrm{CO}_{2} \text { in flue gas } & \text { VLE } & \text { Vaper-Liquid-Equilibrium } \\ F & \text { Molar flow rate of flue gas } & \text { MEA } & \text { Monoethanolamine } \\ m_{\mathrm{S}} & \text { Mass flow rate of solution } & \text { MDEA } & \text { Methyldiethanolamine } \\ q & \text { Mass flow rate of captured } \mathrm{CO}_{2} & \text { PZ } & \text { Piperazine } \\ \mathrm{COP} & \text { Energy conversion efficiency of CCS } & \text { AMP } & \text { 2-amino-2-methyl-1-propanol } \\ \text { Subscripts } & & \text { MAPA } & \text { N-methyl-1,3-propane-diamine } \\ \text { abs } & \text { Absorption } & \text { DEEA } & \text { 2-(diethylamino)-ethanol } \\ \text { des } & \text { Desorption } & \text { AEEA } & \text { 2-((2-aminoethyl) amino) } \\ & & & \text { ethanol } \\ \text { sen } & \text { Sensible } & \text { TETA } & \text { Triethylenetetramine } \\ \text { vap } & \text { Water evaporation } & \text { DEAPD } & \text { 3-(Diethylamino)-1,2-propanediol } \\ \text { re } & \text { Regeneration } & \text { TMPDA } & \text { Tetramethyl-1,3-propanediamine } \\ \text { solv } & \text { MEA solvent } & \text { DMCA } & \text { N, N-dimethylcyclohexylamine }\end{array}$




\section{References}

1. A Daily Record of Atmospheric Carbon Dioxide from Scripps Institution of Oceanography at UC San Diego. Available online: https://scripps.ucsd.edu/programs/keelingcurve/ (accessed on 13 May 2019).

2. Rizvi, R.H.; Newaj, R.; Chaturvedi, O.P.; Prasad, R.; Handa, A.K.; Alam, B. Carbon sequestration and $\mathrm{CO}_{2}$ absorption by agroforestry systems: An assessment for Central Plateau and Hill region of India. J. Earth Syst. Sci. 2019, 128, 56. [CrossRef]

3. Aerenson, T.; Tebaldi, C.; Sanderson, B.; Lamarque, J.F. Changes in a suite of indicators of extreme temperature and precipitation under 1.5 and 2 degrees warming. Environ. Res. Lett. 2018, 13, 035009. [CrossRef]

4. Special Report on Global Warming of $1.5^{\circ} \mathrm{C}$ (Report). Incheon, South Korea; Intergovernmental Panel on Climate Change (IPCC): Geneva, Switzerland, 7 October 2018. Available online: https://www.ipcc.ch/sr15/ (accessed on 13 May 2019).

5. International Energy Agency. Energy Technology Perspectives; International Energy Agency: Paris, France, 2017; Available online: https://webstore.iea.org/energy-technology-perspectives-2017 (accessed on 13 May 2019).

6. Kanniche, M.; Le Moullec, Y.; Authier, O.; Hagi, H.; Bontemps, D.; Neveux, T.; Louis-Louisy, M. Up-to-date $\mathrm{CO}_{2}$ Capture in Thermal Power Plants. Energy Procedia 2017, 114, 95-103. [CrossRef]

7. Mantripragada, H.C.; Zhai, H.; Rubin, E.S. Boundary Dam or Petra Nova-Which is a better model for CCS energy supply? Int. J. Greenh Gas Control 2019, 82, 59-68. [CrossRef]

8. Zhao, R.; Shuai, D.; Li, Z.; Liu, Y.; Tan, Y. Energy-saving pathway exploration of CCS integrated with solar energy: Literature research and comparative analysis. Energy Convers. Manag. 2015, 102, 66-80. [CrossRef]

9. Idem, R.; Wilson, M.; Tontiwachwuthikul, P.; Chakma, A.; Veawab, A.; Aroonwilas, A.; Gelowitz, D. Pilot Plant Studies of the $\mathrm{CO}_{2}$ Capture Performance of Aqueous MEA and Mixed MEA/MDEA Solvents at the University of Regina $\mathrm{CO}_{2}$ Capture Technology Development Plant and the Boundary Dam $\mathrm{CO}_{2}$ Capture Demonstration Plant. Ind. Eng. Chem. Res. 2006, 45, 2414-2420. [CrossRef]

10. Li, X.; Wang, S.; Chen, C. Experimental Study of Energy Requirement of $\mathrm{CO}_{2}$ Desorption from Rich Solvent. Energy Procedia 2013, 37, 1836-1843. [CrossRef]

11. Sakwattanapong, R.; Aroonwilas, A.A.; Veawab, A. Behavior of Reboiler Heat Duty for $\mathrm{CO}_{2}$ Capture Plants Using Regenerable Single and Blended Alkanolamines. Ind. Eng. Chem. Res. 2005, 44, 4465-4473. [CrossRef]

12. Artanto, Y.; Jansen, J.; Pearson, P.; Do, T.; Cottrell, A.; Meuleman, E.; Feron, P. Performance of MEA and amine-blends in the CSIRO PCC pilot plant at Loy Yang Power in Australia. Fuel 2012, 101, $264-275$. [CrossRef]

13. Zhao, B.; Liu, F.; Cui, Z.; Liu, C.; Yue, H.; Tang, S.; Liu, Y.; Lu, H.; Liang, B. Enhancing the energetic efficiency of MDEA/PZ-based $\mathrm{CO}_{2}$ capture technology for a $650 \mathrm{MW}$ power plant: Process improvement. Appl. Energy 2016, 185, 362-375. [CrossRef]

14. Wai, S.K.; Nwaoha, C.; Saiwan, C.; Idem, R.; Supap, T. Absorption heat, solubility, absorption and desorption rates, cyclic capacity, heat duty, and absorption kinetic modeling of AMP-DETA blend for post-combustion $\mathrm{CO}_{2}$ capture. Sep. Purif. Technol. 2018, 194, 89-95. [CrossRef]

15. Mangalapally, H.P.; Hasse, H. Pilot plant study of two new solvents for post combustion carbon dioxide capture by reactive absorption and comparison to monoethanolamine. Chem. Eng. Sci. 2011, 66, 5512-5522. [CrossRef]

16. Rabensteiner, M.; Kinger, G.; Koller, M.; Hochenauer, C. Pilot plant study of aqueous solution of piperazine activated 2-amino-2-methyl-1-propanol for post combustion carbon dioxide capture. Int. J. Greenh. Gas. Control 2016, 51, 106-117. [CrossRef]

17. Yang, J.; Yu, X.; Yan, J.; Tu, S.T. $\mathrm{CO}_{2}$ capture using amine solution mixed with ionic liquid. Ind. Eng. Chem. Res. 2014, 53, 2790-2799. [CrossRef]

18. Bernard, F.L.; Dalla Vecchia, F.; Rojas, M.F.; Ligabue, R.; Vieira, M.O.; Costa, E.M.; Chaban, V.V.; Einloft, S. Anticorrosion Protection by Amine-Ionic Liquid Mixtures: Experiments and Simulations. J. Chem. Eng. Data 2016, 61, 1803-1810. [CrossRef]

19. Akinola, T.E.; Oko, E.; Wang, M. Study of $\mathrm{CO}_{2}$ removal in natural gas process using mixture of ionic liquid and MEA through process simulation. Fuel 2019, 236, 135-146. [CrossRef]

20. Zacchello, B.; Oko, E.; Wang, M.; Fethi, A. Process simulation and analysis of carbon capture with an aqueous mixture of ionic liquid and monoethanolamine solvent. Int. J. Coal Sci. Technol. 2017, 4, 25-32. [CrossRef] 
21. Ying, H.; Zhang, X.; Xin, Z.; Dong, H.; Zhang, S. Thermodynamic Modeling and Assessment of Ionic Liquid-Based $\mathrm{CO}_{2}$ Capture Processes. Ind. Eng. Chem. Res. 2014, 53, 11805-11817.

22. Mobley, P.D.; Rayer, A.V.; Tanthana, J.; Gohndrone, T.R.; Soukri, M.; Coleman, L.J.; Lail, M. CO 2 Capture Using Fluorinated Hydrophobic Solvents. Ind. Eng. Chem. Res. 2017, 56, 11958-11966. [CrossRef]

23. Yu, Y.S.; Lu, H.F.; Zhang, T.T.; Zhang, Z.X.; Wang, G.X.; Rudolph, V. Determining the Performance of an Efficient Nonaqueous $\mathrm{CO}_{2}$ Capture Process at Desorption Temperatures below 373 K. Ind. Eng. Chem. Res. 2013, 52, 12622-12634. [CrossRef]

24. Guo, H.; Li, C.; Shi, X.; Li, H.; Shen, S. Nonaqueous amine-based absorbents for energy efficient $\mathrm{CO}_{2}$ capture. Appl. Energy 2019, 239, 725-734. [CrossRef]

25. Zhu, K.; Lu, H.; Liu, C.; Wu, K.; Jiang, W.; Cheng, J.; Tang, S.; Yue, H.; Liu, Y.; Liang, B. Investigation on the Phase-Change Absorbent System MEA + Solvent A (SA) $+\mathrm{H}_{2} \mathrm{O}$ Used for the $\mathrm{CO}_{2}$ Capture from Flue Gas. Ind. Eng. Chem. Res. 2019, 58, 3811-3821. [CrossRef]

26. Zhang, W.; Jin, X.; Tu, W.; Ma, Q.; Mao, M.; Cui, C. Development of MEA-based $\mathrm{CO}_{2}$ phase change absorbent. Appl. Energy 2017, 195, 316-323. [CrossRef]

27. Zhang, J.; Yu, Q.; Agar, D.W. Improvement of Lipophilic-Amine-based Thermomorphic Biphasic Solvent for Energy-Efficient Carbon Capture. Energy Procedia 2012, 23, 92-101. [CrossRef]

28. Pinto, D.D.D.; Knuutila, H.; Fytianos, G.; Haugen, G.; Mejdell, T.; Svendsen, H.F. $\mathrm{CO}_{2}$ post combustion capture with a phase change solvent. Pilot plant campaign. Int. J. Greenh. Gas Control 2014, 31, 153-164. [CrossRef]

29. Shen, Y.; Jiang, C.; Zhang, S.; Chen, J.; Wang, L.; Chen, J. Biphasic solvent for $\mathrm{CO}_{2}$ capture: Amine property-performance and heat duty relationship. Appl. Energy 2018, 230, 726-733. [CrossRef]

30. Liu, F.; Fang, M.; Dong, W.; Wang, T.; Xia, Z.; Wang, Q.; Luo, Z. Carbon dioxide absorption in aqueous alkanolamine blends for biphasic solvents screening and evaluation. Appl. Energy 2019, 233-234, 468-477. [CrossRef]

31. Zhang, S.; Shen, Y.; Shao, P.; Chen, J.; Wang, L. Kinetics, Thermodynamics, and Mechanism of a Novel Biphasic Solvent for $\mathrm{CO}_{2}$ Capture from Flue Gas. Environ. Sci. Technol. 2018, 52, 3660-3668. [CrossRef]

32. Cuccia, L.; Dugay, J.; Bontemps, D.; Louis-Louisy, M.; Morand, T.; Kanniche, M.; Bellosta, V.; Vial, J. Monitoring of the blend monoethanolamine/methyldiethanolamine/water for post-combustion $\mathrm{CO}_{2}$ capture. Int. J. Greenh. Gas Control 2019, 80, 43-53. [CrossRef]

33. Gladis, A.; Lomholdt, N.F.; Fosbøl, P.L.; Woodley, J.M.; von Solms, N. Pilot scale absorption experiments with carbonic anhydrase-enhanced MDEA-Benchmarking with $30 \mathrm{wt} \%$ MEA. Int. J. Greenh. Gas Control 2019, 82, 69-85. [CrossRef]

34. Hadri, N.E.; Dang, V.Q.; Goetheer, E.L.V.; Zahra, M.R.M.A. Aqueous amine solution characterization for post-combustion $\mathrm{CO}_{2}$ capture process. Appl. Energy 2016, 185, 1433-1449. [CrossRef]

35. Bougie, F.; Iliuta, M.C. Sterically Hindered Amine-Based Absorbents for the Removal of $\mathrm{CO}_{2}$ from Gas Streams. J. Chem. Eng. Data 2012, 57, 635-669. [CrossRef]

36. Ahmady, A.; Hashim, M.A.; Aroua, M.K. Experimental Investigation on the Solubility and Initial Rate of Absorption of $\mathrm{CO}_{2}$ in Aqueous Mixtures of Methyldiethanolamine with the Ionic Liquid 1-Butyl-3-methylimidazolium Tetrafluoroborate. J. Chem. Eng. Data 2010, 55, 5733-5738. [CrossRef]

37. Haider, M.B.; Hussain, Z.; Kumar, R. $\mathrm{CO}_{2}$ absorption and kinetic study in ionic liquid amine blends. J. Mol. Liq. 2016, 224, 1025-1031. [CrossRef]

38. Kumar, S.; Cho, J.H.; Moon, I. Ionic liquid-amine blends and $\mathrm{CO}_{2}$ BOLs: Prospective solvents for natural gas sweetening and $\mathrm{CO}_{2}$ capture technology-A review. Int. J. Greenh. Gas Control 2014, 20, 87-116. [CrossRef]

39. Gao, J.; Cao, L.; Dong, H.; Zhang, X.; Zhang, S. Ionic liquids tailored amine aqueous solution for pre-combustion $\mathrm{CO}_{2}$ capture: Role of imidazolium-based ionic liquids. Appl. Energy 2015, 154, 771-780. [CrossRef]

40. Camper, D.; Bara, J.E.; Gin, D.L.; Noble, R.D. Room-temperature ionic liquid-amine solutions: Tunable solvents for efficient and reversible capture of $\mathrm{CO}_{2}$. Ind. Eng. Chem. Res. 2008, 47, 8496-8498. [CrossRef]

41. Zhai, H.; Rubin, E.S. Systems Analysis of Ionic Liquids for Post-combustion $\mathrm{CO}_{2}$ Capture at Coal-fired Power Plants. Energy Procedia 2014, 63, 1321-1328. [CrossRef]

42. Ramdin, M.; De Loos, T.W.; Vlugt, T.J.H. State-of-the-art of $\mathrm{CO}_{2}$ capture with ionic liquids. Ind. Eng. Chem. Res. 2012, 51, 8149-8177. [CrossRef] 
43. Chao, G.; Chen, S.; Zhang, Y.; Wang, G. Solubility of $\mathrm{CO}_{2}$ in Nonaqueous Absorption System of 2-(2-Aminoethylamine) ethanol + Benzyl Alcohol. J. Chem. Eng. Data 2014, 59, 1796-1801.

44. Dinda, S.; Goud, V.V.; Patwardhan, A.V.; Pradhan, N.C. Kinetics of reactive absorption of carbon dioxide with solutions of 1,6-hexamethylenediamine in polar protic solvents. Sep. Purif. Technol. 2010, 75, 1-7. [CrossRef]

45. Chen, S.; Hu, G.; Smith, K.H.; Mumford, K.A.; Zhang, Y.; Stevens, G.W. Kinetics of $\mathrm{CO}_{2}$ Absorption in an Ethylethanolamine Based Solution. Ind. Eng. Chem. Res. 2017, 56, 12305-12315. [CrossRef]

46. Yu, C.H.; Wu, T.W.; Tan, C.S. $\mathrm{CO}_{2}$ capture by piperazine mixed with non-aqueous solvent diethylene glycol in a rotating packed bed. Int. J. Greenh. Gas Control 2013, 19, 503-509. [CrossRef]

47. Leimbrink, M.; Sandkämper, S.; Wardhaugh, L.; Maher, D.; Green, P.; Puxty, G.; Conway, W.; Bennett, R.; Botma, H.; Feron, P.; et al. Energy-efficient solvent regeneration in enzymatic reactive absorption for carbon dioxide capture. Appl. Energy 2017, 208, 263-276. [CrossRef]

48. Akachuku, A.; Osei, P.A.; Decardi-Nelson, B.; Srisang, W.; Pouryousefi, F.; Ibrahim, H.; Idem, R. Experimental and kinetic study of the catalytic desorption of $\mathrm{CO}_{2}$ from $\mathrm{CO}_{2}$-loaded monoethanolamine (MEA) and blended monoethanolamine - Methyl-diethanolamine (MEA-MDEA) solutions. Energy 2019, 179, 475-489. [CrossRef]

49. Lai, Q.; Toan, S.; Assiri, M.A.; Cheng, H.; Russell, A.G.; Adidharma, H.; Radosz, M.; Fan, M. Catalyst-TiO(OH $)_{2}$ could drastically reduce the energy consumption of $\mathrm{CO}_{2}$ capture. Nat. Commun. 2018, 9, 2672. [CrossRef]

50. Rabensteiner, M.; Kinger, G.; Koller, M.; Hochenauer, C. Three years of working experience with different solvents at a realistic post combustion capture pilot plant. Energy Procedia 2014, 63, 1578-1584. [CrossRef]

51. Stec, M.; Tatarczuk, A.; Więcław-Solny, L.; Krótki, A.; Ciązko, M.; Tokarski, S. Pilot plant results for advanced $\mathrm{CO}_{2}$ capture process using amine scrubbing at the Jaworzno II Power Plant in Poland. Fuel 2015, 151, 50-56. [CrossRef]

52. Krótki, A.; Więcław-Solny, L.; Tatarczuk, A.; Stec, M.; Wilk, A.; Śpiewak, D.; Spietz, T. Laboratory Studies of Post-combustion $\mathrm{CO}_{2}$ Capture by Absorption with MEA and AMP Solvents. Arab. J. Sci. Eng. 2016, 41, 371-379. [CrossRef]

53. Wiecław-Solny, L.; Tatarczuk, A.; Stec, M.; Krótki, A. Advanced $\mathrm{CO}_{2}$ capture pilot plant at tauron's coal-fired power plant: Initial results and further opportunities. Energy Procedia 2014, 63, 6318-6322. [CrossRef]

54. Knudsen, J.N.; Andersen, J.; Jensen, J.N.; Biede, O. Evaluation of process upgrades and novel solvents for the post combustion $\mathrm{CO}_{2}$ capture process in pilot-scale. Energy Procedia 2011, 4, 1558-1565. [CrossRef]

55. Knudsen, J.N.; Jensen, J.N.; Vilhelmsen, P.J.; Biede, O. Experience with $\mathrm{CO}_{2}$ capture from coal flue gas in pilot-scale: Testing of different amine solvents. Energy Procedia 2009, 1, 783-790. [CrossRef]

56. Moser, P.; Schmidt, S.; Sieder, G.; Garcia, H.; Stoffregen, T.; Stamatov, V. The post-combustion capture pilot plant Niederaussem-Results of the first half of the testing programme. Energy Procedia 2011, 4, 1310-1316. [CrossRef]

57. Feron, P.H.; Cousins, A.; Gao, S.; Liu, L.; Wang, J.; Wang, S.; Niu, H.; Yu, H.; Li, K.; Cottrell, A. Experimental performance assessment of a mono-ethanolamine-based post-combustion $\mathrm{CO}_{2}$ capture at a coal-fired power station in China. Greenh. Gas Sci. Technol. 2017, 7, 486-499. [CrossRef]

58. Mangalapally, H.P.; Hasse, H. Pilot plant study of post-combustion carbon dioxide capture by reactive absorption: Methodology, comparison of different structured packings, and comprehensive results for monoethanolamine. Chem. Eng. Res. Des. 2011, 89, 1216-1228. [CrossRef]

59. Nakamura, S.; Yamanaka, Y.; Matsuyama, T.; Okuno, S.; Sato, H. IHI s amine-based $\mathrm{CO}_{2}$ capture technology for coal fired power plant. Energy Procedia 2013, 37, 1897-1903. [CrossRef]

60. Vitse, F.; Baburao, B.; Dugas, R.; Czarnecki, L.; Schubert, C. Technology and pilot plant results of the advanced amine process. Energy Procedia 2011, 4, 5527-5533. [CrossRef]

61. House, K.Z.; Harvey, C.F.; Aziz, M.J.; Schrag, D.P. The energy penalty of post-combustion $\mathrm{CO}_{2}$ capture storage and its implications for retrofitting the U.S. installed base. Energy Environ. Sci. 2009, 2, 193-205. [CrossRef]

62. Ruthven, D.M. $\mathrm{CO}_{2}$ capture: Value functions, separative work and process economics. Chem. Eng. Sci. 2014, 114, 128-133. [CrossRef]

63. Wu, Y.; Wu, F.; Hu, G.; Mirza, N.R.; Stevens, G.W.; Mumford, K.A. Modelling of a post-combustion carbon dioxide capture absorber using potassium carbonate solvent in Aspen Custom Modeller. Chin. J. Chem. Eng. 2018, 26, 2327-2336. [CrossRef] 
64. Mores, P.; Scenna, N.; Mussati, S. A rate based model of a packed column for $\mathrm{CO}_{2}$ absorption using aqueous monoethanolamine solution. Int. J. Greenh. Gas Control 2012, 6, 21-36. [CrossRef]

65. Wang, J.; Sun, T.; Zhao, J.; Deng, S.; Li, K.; Xu, Y.; Fu, J. Thermodynamic considerations on MEA absorption: Whether thermodynamic cycle could be used as a tool for energy efficiency analysis. Energy 2019, 168, 380-392. [CrossRef]

66. Simon, L.L.; Elias, Y.; Puxty, G.; Artanto, Y.; Hungerbuhler, K. Rate based modeling and validation of a carbon-dioxide pilot plant absorbtion column operating on monoethanolamine. Chem. Eng. Res. Des. 2011, 89, 1684-1692. [CrossRef]

67. Kvamsdal, H.M.; Rochelle, G.T. Effects of the temperature bulge in $\mathrm{CO}_{2}$ absorption from flue gas by aqueous monoethanolamine. Ind. Eng. Chem. Res. 2008, 47, 867-875. [CrossRef]

68. Qing, X. Thermodynamics of $\mathrm{CO}_{2}$ Loaded Aqueous Amines. Ph.D. Thesis, University of Texas Libraries, Austin, TX, USA, 2011.

69. $\mathrm{Xu}, \mathrm{Q}$.; Rochelle, $\mathrm{G}$. Total pressure and $\mathrm{CO}_{2}$ solubility at high temperature in aqueous amines. Energy Procedia 2011, 4, 117-124. [CrossRef]

70. Wang, T.; Yu, W.; Le Moullec, Y.; Liu, F.; Xiong, Y.; He, H.; Lu, J.; Hsu, E.; Fang, M.; Luo, Z. Solvent regeneration by novel direct non-aqueous gas stripping process for post-combustion $\mathrm{CO}_{2}$ capture. Appl. Energy 2017, 205, 23-32. [CrossRef]

71. Morris, D.R.; Szargut, J. Standard chemical exergy of some elements and compounds on the planet earth. Energy 1986, 11, 733-755. [CrossRef]

72. Zhao, R.; Deng, S.; Liu, Y.; Zhao, Q.; He, J.; Zhao, L. Carbon pump: Fundamental theory and applications. Energy 2017, 119, 1131-1143. [CrossRef]

(C) 2019 by the authors. Licensee MDPI, Basel, Switzerland. This article is an open access article distributed under the terms and conditions of the Creative Commons Attribution (CC BY) license (http://creativecommons.org/licenses/by/4.0/). 